\title{
Effect of dietary arginine on growth, intestinal enzyme activities and gene expression in muscle, hepatopancreas and intestine of juvenile Jian carp (Cyprinus carpio var. Jian)
}

\author{
Gangfu Chen ${ }^{1}$, Lin Feng ${ }^{1,2,3}$, Shengyao Kuang ${ }^{1,4}$, Yang Liu ${ }^{1,2,3}$, Jun Jiang ${ }^{1,2,3}$, Kai Hu ${ }^{1,2,3}$, \\ Weidan Jiang ${ }^{1,2,3}$, Shuhong $\mathrm{Li}^{1}$, Ling Tang ${ }^{1,4}$ and Xiaoqiu Zhou ${ }^{1,2,3 *}$ \\ ${ }^{1}$ Animal Nutrition Institute, Sichuan Agricultural University, Sichuan, Ya'an 625014, People's Republic of China \\ ${ }^{2}$ Fish Nutrition and Safety in Production Sichuan University Key Laboratory, Sichuan Agricultural University, Sichuan, \\ Ya'an 625014, People's Republic of China \\ ${ }^{3}$ Key Laboratory for Animal Disease-Resistance Nutrition of China Ministry of Education, Sichuan Agricultural University, \\ Sichuan, Ya'an 625014, People's Republic of China \\ ${ }^{4}$ Animal Nutrition Institute, Sichuan Academy of Animal Science, Chengdu 610066, People's Republic of China \\ (Submitted 14 March 2011 - Final revision received 30 August 2011 - Accepted 6 September 2011 - First published online 21 October 2011)
}

Abstract

The present study was conducted to test the hypothesis that dietary arginine promotes digestion and absorption capacity, and, thus, enhances fish growth. This improvement might be related to the target of rapamycin (TOR) and eIF4E-binding protein (4E-BP). A total of 1200 juvenile Jian carp, Cyprinus carpio var. Jian, with an average initial weight of 6.33 (sE 0.03 ) g, were fed with diets containing graded concentrations of arginine, namely, 9.8 (control), 12.7, 16.1, 18.5, 21.9 and 24.5 g arginine/kg diet for 9 weeks. An real-time quantitative PCR analysis was performed to determine the relative expression of TOR and 4E-BP in fish muscle, hepatopancreas and intestine. Dietary arginine increased $(P<0.05)$ : (1) glutamate-oxaloacetate transaminase and glutamate-pyruvate transaminase activities in muscle and hepatopancreas; (2) intestine and hepatopancreas protein content, folds height, and trypsin, chymotrypsin, lipase, $\mathrm{Na}^{+} / \mathrm{K}^{+}-\mathrm{ATPase}$, alkaline phosphatase, $\gamma$-glutamyl transpeptidase and creatine kinase activities in intestine; (3) Lactobacillus counts; (4) relative expression of TOR in the muscle, hepatopancreas and distal intestine (DI); (5) relative expression of 4E-BP in proximal intestine (PI) and mid-intestine (MI), as compared with the control group. In contrast, dietary arginine reduced $(P<0.05)$ : (1) plasma ammonia content; (2) Aeromonas bydrophila and Escherichia coli counts; (3) relative expression of TOR in PI and MI; (4) relative expression of 4E-BP in the muscle, hepatopancreas and DI. The arginine requirement estimated by specific growth rate using quadratic regression analysis was found to be $18.0 \mathrm{~g} / \mathrm{kg}$ diet. These results indicate that arginine improved fish growth, digestive and absorptive ability and regulated the expression of $T O R$ and $4 E-B P$ genes.

Key words: Arginine: Intestinal enzyme activities: Target of rapamycin: Cyprinus carpio var. Jian

Arginine is an essential amino acid for optimal fish growth ${ }^{(1)}$. Dietary arginine deficiency causes growth reduction and poor protein retention, as shown in coho salmon (Oncorbynchus kisutch), European sea bass (Dicentrarchus labrax) and Indian major carp (Cirrbinus mrigala) ${ }^{(2-4)}$. Protein deposition in fish is mainly associated with amino acid metabolism ${ }^{(5)}$. Glutamate oxaloacetate transaminase (GOT) and glutamate pyruvate transaminase (GPT) are two important amino acid metabolic enzymes of fish ${ }^{(6)}$. Furthermore, ammonia was found to correlate with fish amino acid metabolism ${ }^{(7,8)}$.
An increase in plasma ammonia nitrogen concentration was observed in the European sea bass fed with plant protein diets under a moderate or large excess of dietary arginine ${ }^{(9)}$. However, no study addressed the effects of arginine on GOT and GPT in fish. Recently, our laboratory reported that supplementation with methionine hydroxy analogue to practical diets decreased plasma ammonia levels and increased GOT and GPT activities in Jian carp (Cyprinus carpio var. Jian) hepatopancreas and muscle ${ }^{(10)}$. Accordingly, further studies are required to address the effect of arginine on amino acid metabolism in fish.

Abbreviations: $\boldsymbol{\gamma}$-GT, $\boldsymbol{\gamma}$-glutamyl transpeptidase; 4E-BP, eIF4E-binding protein; AKP, alkaline phosphatase; CK, creatine kinase; DI, distal intestine; FE, feed efficiency; FI, feed intake; GOT, glutamate oxaloacetate transaminase; GPT, glutamate pyruvate transaminase; IEC, intestinal epithelial cells; ISI, intestosomatic index; MI, mid-intestine; PAC, plasma ammonia content; PI, proximal intestine; PRV, protein retention value; RGL, relative gut length; SGR, specific growth rate; TOR, target of rapamycin.

*Corresponding author: Dr X. Zhou, fax +86 835 2885968, email zhouxq@sicau.edu.cn; xqzhouqq@tom.com 
Fish growth rate is dependent on digestive and absorptive ability ${ }^{(11,12)}$. Digestion ability and absorption function were found to correlate with the growth and development of digestive organs ${ }^{(13)}$. Several studies ${ }^{(14-17)}$ demonstrated that arginine and its intermediate had a beneficial influence on the pancreas and intestine by promoting tissue integrity and cell proliferation. However, studies on the effects of dietary arginine on the growth and development of fish digestive organs are limited. Digestion and absorption of nutrients depend on the activity of digestive enzymes and brush-border membrane enzymes ${ }^{(18)}$. Fish exocrine pancreas synthesises and secretes a large number of digestive enzymes into the intestinal lumen, such as trypsin, chymotrypsin, lipase and amylase $e^{(19,20)}$. Alkaline phosphatase (AKP), $\mathrm{Na}^{+} / \mathrm{K}^{+}$ATPase and creatine kinase (CK) are considered to be involved in the absorption of nutrients in fish ${ }^{(21)}$. However, few studies have been conducted to investigate the effects of dietary arginine on fish intestinal enzyme activities. Synthesis and secretion of digestive enzymes from pancreatic exocrine tissue are sensitive to the redox state, which can be regulated by $\mathrm{NO}^{(22-25)}$. Moreover, studies have indicated that arginine residues have an important role in digestive and absorptive enzymes ${ }^{(26-32)}$. Studies from our laboratory have shown that glutamine, lysine and methionine improve digestive and brush-border membrane enzyme activities $^{(33-35)}$. Hence, it is necessary to address the relationship between arginine and fish intestinal enzyme activities.

The intestinal microbiota contributes to host health status, and alterations in the microbial balance may produce detrimental effects in hosts ${ }^{(36,37)}$. A recent study has found that dietary methionine and protein improved Lactobacillus counts and reduced Escherichia coli and Aeromonas counts in juvenile Jian carp ${ }^{(35,38)}$. Furthermore, dietary arginine supplementation decreased the frequency of Helicobacter spp. and Clostridium perfringens in rabbit ileum ${ }^{(39)}$. However, few studies have evaluated the effects of arginine on fish intestinal microbial populations.

Protein synthesis is a key component of the processes involved in growth response ${ }^{(40)}$. The limiting step in protein synthesis is translation initiation, which is regulated by the signalling pathway of target of rapamycin (TOR) through eIF4E-binding protein (4E-BP) 1 and ribosomal protein $\mathrm{S} 6$ kinase $^{(41)}$. TOR and $4 E-B P$ genes were cloned in our laboratory. Similarly, the mRNA expression of TOR decreased with dietary Thr and Trp levels in the intestine and muscle and increased with Gln supplementation in intestinal epithelial cells (IEC) of Jian carp (L Tang, L Feng and XQ Zhou, unpublished results). However, no study has addressed the effects of arginine on TOR and 4E-BP expression in fish tissues or organs. Moreover, the nutritional regulation of major kinases involved in the TOR pathway has been elucidated in fish. Re-feeding was found to enhance the phosphorylation of TOR in rainbow trout (Oncorhynchus mykiss) muscle and liver and promote the phosphorylation of $4 \mathrm{E}-\mathrm{BP} 1$ in rainbow trout muscle ${ }^{(42,43)}$. Therefore, arginine might be related to the expression of TOR and $4 E-B P$ genes in fish, which needs to be investigated.

Jian carp is the first variety of common carp ${ }^{(44)}$. Its gross production is approximately more than $30 \%$ greater than other varieties of common carp, and it has a high flesh quality ${ }^{(44,45)}$. Interestingly, it has become one of the most popular species for fish culture in China ${ }^{(46)}$. The present study was designed to test the hypothesis that dietary arginine promotes digestion and absorption capacity that can enhance Jian carp growth, which might be related to the expression of $T O R$ and $4 E-B P$ genes.

\section{Materials and methods}

\section{Experimental diets and procedure}

The composition of the tested diets is given in Table 1 . Fishmeal, rice gluten meal and crystalline amino acids were used as the main protein sources and were found to be limiting in arginine. Crystalline amino acids (Donboo Amino Acid, Nantong, Jiangsu, China) were used to simulate the amino acid profile of diets with $34 \%$ whole chicken egg protein, except for arginine. The experimental diets were supplemented with L-arginine hydrochloride to provide arginine at the concentrations of $9 \cdot 0,12 \cdot 0,15 \cdot 0,18 \cdot 0,21 \cdot 0$ and $24 \cdot 0 \mathrm{~g} / \mathrm{kg}$ of diet. All diets were made iso-nitrogenous and iso-energetic $(16.5 \mathrm{~kJ} / \mathrm{g}$ of gross energy) with the addition of appropriate amounts of glycine. $\mathrm{Zn}, \mathrm{Fe}$, pyridoxine, pantothenic acid, inositol, riboflavin and thiamin were formulated to meet the nutrient requirements of Jian carp according to previous studies conducted in our laboratory ${ }^{(47-53)}$. The levels of other nutrients met the requirements for common carp according to the National Research Council ${ }^{(54)}$. The $\mathrm{pH}$ of each diet was adjusted to 7.0 by gradually adding $6.0 \mathrm{M}-\mathrm{NaOH}^{(10)}$. Pellets were produced and stored at $-20^{\circ} \mathrm{C}$ until use ${ }^{(55)}$. The arginine concentrations in experimental diets were determined to be $9 \cdot 8$ (control), 12.7, 16.1, 18.5, 21.9 and $24.5 \mathrm{~g}$ arginine/ $\mathrm{kg}$ diet, as described by Wu et al. ${ }^{(56)}$ using an Agilent 1100 series HPLC (Agilent Technologies, Palo Alto, CA, USA).

All experimental protocols were approved by the Animal Care Advisory Committee of Sichuan Agricultural University. Juvenile Jian carp were obtained from the Tong Wei Hatchery (Sichuan, China). After an acclimatisation period of 4 weeks to laboratory conditions, 1200 carp, with a mean initial weight of 6.33 (SE 0.03$) \mathrm{g}$, were randomly distributed into twenty-four glass aquaria $\left(90 \times 30 \times 40 \mathrm{~cm}^{3}\right)$, resulting in fifty juveniles in each aquarium. Each experimental diet was randomly assigned to aquaria in quadruplicate. Fish were fed with their respective diets to apparent satiation six times per $\mathrm{d}$ for the first 4 weeks and four times per $\mathrm{d}$ from the fifth to the ninth week. Uneaten feed was removed by siphoning at $30 \mathrm{~min}$ after feeding, dried and weighted to measure feed intake (FI). Water quality, closed water recirculating and oxygen auto-supplemented system were maintained as previously described by our laboratory ${ }^{(51)}$. Briefly, the water flow rate in each aquarium was maintained at 1.2 litres $/ \mathrm{min}$; water was drained through biofilters to remove solid substances and reduce ammonia concentration. Water temperature, $\mathrm{pH}$ and dissolved oxygen were $26 \pm 1^{\circ} \mathrm{C}, 7 \cdot 0 \pm 0 \cdot 3$ and 5.0 (SD 0.3$) \mathrm{mg} / \mathrm{l}$, respectively. The experimental units were maintained under a natural light and dark cycle. 
Table 1. Composition ( $\mathrm{g} / \mathrm{kg}$ dry diet) of experimental diets used for determining the effects of dietary arginine on the growth and biochemical activities of Jian carp (Cyprinus carpio var. Jian)

\begin{tabular}{|c|c|c|c|c|c|c|}
\hline \multirow[b]{2}{*}{ Ingredients } & \multicolumn{6}{|c|}{ Diets } \\
\hline & Diet 1 & Diet 2 & Diet 3 & Diet 4 & Diet 5 & Diet 6 \\
\hline Fishmeal & 100 & 100 & 100 & 100 & 100 & 100 \\
\hline Rice gluten meal & 162 & 162 & 162 & 162 & 162 & 162 \\
\hline Amino acid mix $^{*}$ & $135 \cdot 6$ & $135 \cdot 6$ & $135 \cdot 6$ & $135 \cdot 6$ & $135 \cdot 6$ & $135 \cdot 6$ \\
\hline$\alpha$-Starch & 320 & 320 & 320 & 320 & 320 & 320 \\
\hline Maize starch & $153 \cdot 3$ & 155.4 & $157 \cdot 6$ & $159 \cdot 7$ & 161.9 & $161 \cdot 0$ \\
\hline Fish oil & $21 \cdot 8$ & $21 \cdot 8$ & $21 \cdot 8$ & $21 \cdot 8$ & $21 \cdot 8$ & $21 \cdot 8$ \\
\hline Soya bean oil & 8 & 8 & 8 & 8 & 8 & 8 \\
\hline Mineral premix† & $31 \cdot 6$ & $31 \cdot 6$ & $31 \cdot 6$ & $31 \cdot 6$ & $31 \cdot 6$ & $31 \cdot 6$ \\
\hline Vitamin premix $\ddagger$ & 11.3 & 11.3 & $11 \cdot 3$ & 11.3 & $11 \cdot 3$ & 11.3 \\
\hline Ethoxyquin & 0.5 & 0.5 & 0.5 & 0.5 & 0.5 & 0.5 \\
\hline$\alpha$-Cellulose & 30 & 30 & 30 & 30 & 30 & 30 \\
\hline L-Arg-HCL & 0 & $3 \cdot 6$ & $7 \cdot 3$ & $10 \cdot 9$ & 14.5 & $18 \cdot 2$ \\
\hline L-Gly & $25 \cdot 9$ & $20 \cdot 2$ & $14 \cdot 3$ & $8 \cdot 6$ & $2 \cdot 8$ & 0 \\
\hline \multicolumn{7}{|l|}{ Nutrient content§ } \\
\hline Calculated crude protein & $340 \cdot 0$ & $340 \cdot 0$ & $340 \cdot 0$ & $340 \cdot 0$ & $340 \cdot 0$ & $340 \cdot 0$ \\
\hline Analysed crude protein & $330 \cdot 0$ & $330 \cdot 0$ & $330 \cdot 0$ & $330 \cdot 0$ & $330 \cdot 0$ & $330 \cdot 0$ \\
\hline Gross energy $(\mathrm{kJ} / \mathrm{g})$ & $16 \cdot 5$ & $16 \cdot 5$ & $16 \cdot 5$ & $16 \cdot 5$ & $16 \cdot 5$ & $16 \cdot 5$ \\
\hline Arg & $9 \cdot 8$ & $12 \cdot 7$ & $16 \cdot 1$ & 18.5 & $21 \cdot 9$ & 24.5 \\
\hline
\end{tabular}

${ }^{*}$ Amino acid mix: lysine, $15.060 \mathrm{~g}$; methionine, $8.265 \mathrm{~g}$; threonine, $11.584 \mathrm{~g}$; tryptophan, $1.523 \mathrm{~g}$; histidine, $3.240 \mathrm{~g}$; isoleucine, $1.362 \mathrm{~g}$; phenylalanine, $7.232 \mathrm{~g}$; valine, $1.305 \mathrm{~g}$; glycine, $86.028 \mathrm{~g}$.

† Mineral mixture (g/kg mixture): $\mathrm{FeSO}_{4} \cdot 7 \mathrm{H}_{2} \mathrm{O}, 45 \cdot 767 \mathrm{~g} ; \mathrm{CuSO}_{4} \cdot 5 \mathrm{H}_{2} \mathrm{O}, 1.201 \mathrm{~g} ; \mathrm{ZnSO}_{4} \cdot 7 \mathrm{H}_{2} \mathrm{O}, 14 \cdot 113 \mathrm{~g} ; \mathrm{MnSO}_{4}$ $\mathrm{H}_{2} \mathrm{O}, 4.089 \mathrm{~g} ; \mathrm{KI}, 2.895 \mathrm{~g} ; \mathrm{NaSeO}_{3}, 2.500 \mathrm{~g} ; \mathrm{CaCO}_{3}, 929.436 \mathrm{~g} . \mathrm{Ca}\left(\mathrm{H}_{2} \mathrm{PO}_{4}\right)_{2}, 21.6 \mathrm{~g} / \mathrm{kg}$ dry diet.

$\ddagger$ Vitamin mixture $(\mathrm{g} / \mathrm{kg}$ mixture): retinyl acetate $(172 \mathrm{mg} / \mathrm{g}), 0.800 \mathrm{~g} ;$ cholecalciferol $(12.5 \mathrm{mg} / \mathrm{g}), 0.480 \mathrm{~g}$ $\mathrm{D}, \mathrm{L}-\alpha$-tocopherol acetate $(50 \%), 20.000 \mathrm{~g}$; menadione $(23 \%), 0.220 \mathrm{~g}$; thiamine hydrochloride $(90 \%), 0.113 \mathrm{~g}$; riboflavin $(80 \%), 0.625 \mathrm{~g}$; pyridoxine hydrochloride $(81 \%), 0.749 \mathrm{~g}$; cyanocobalamin $(1 \%), 0.100 \mathrm{~g}$; niacin (99\%), 4.165 g; D-biotin (2\%), $5.000 \mathrm{~g}$; meso-inositol (99\%), $52.323 \mathrm{~g}$; folic acid (96\%), $0.521 \mathrm{~g}$; ascorhyl acetate (93\%), $7.161 \mathrm{~g}$; calcium-D-pantothenate $(90 \%), 2.558 \mathrm{~g}$. choline chloride, $1.3 \mathrm{~g} / \mathrm{kg}$ dry diet.

$\S$ Nutrient content: lysine, 20; methionine + cystine, 15; $n-3+n-6,20$; available phosphorus, 6 . Gross energy was calculated on the basis of fuel values $19.14,13.65,24.27,16.02,14.81$ and $37.65 \mathrm{~kJ} / \mathrm{g}$ for fishmeal, rice gluten meal, amino acids, $\alpha$-starch, maize starch and fat, respectively.

\section{Sample collection and analysis}

The procedures of sample collection were similar to those previously described in other studies conducted in our laboratory $^{(57)}$. After 12 -h fasting, fish from each aquaria were counted and weighed at the beginning and at the end of the feeding trial. At the beginning of the experiment, thirty fish from the same population used in the experiment were collected to determine the initial carcass proximate composition. At the end of the feeding trial, four fish from each aquarium were collected and frozen for estimating the final carcass proximate composition. A total of fifteen fish from each aquarium were anaesthetised in a benzocaine bath $(50 \mathrm{mg} / \mathrm{l})$, as described by Berdikova Bohne et al. ${ }^{(58)}$, with a minor modification; then, the hepatopancreas, intestine and muscle were quickly collected and stored at $-70^{\circ} \mathrm{C}$ until analysis. Another four fish from each aquarium were randomly collected for obtaining blood samples from the caudal vein with heparinised syringes, at $6 \mathrm{~h}$ after the last feeding, for plasma ammonia determination. The intestines of another four fish from each aquarium were used to measure the height of intestinal folds, according to Lin \& Zhou ${ }^{(33)}$. The digesta of another three fish collected from each aquarium were sampled to determine intestinal microbial populations.

Proximate analysis of diets and whole body samples were performed according to methods of the Association of Official Analytical Chemists ${ }^{(59)}$. Muscle, intestine and hepatopancreas were homogenised in ten volumes $(\mathrm{w} / \mathrm{v})$ of ice-cold physiological saline solution and centrifuged at $6000 \mathrm{~g}$ for $20 \mathrm{~min}$ at $4^{\circ} \mathrm{C}$; then, the supernatant was stored. GOT and GPT activities in muscle and hepatopancreas were determined with the method of Bergmeyer \& Bernt ${ }^{(60,61)}$. Blood was centrifuged at $4000 \mathrm{~g}$ for $15 \mathrm{~min}$; then, the supernatant fluid was collected for ammonia determination, as described by Tantikitti \& Chimsung ${ }^{(62)}$. Trypsin and chymotrypsin activities were determined according to Hummel ${ }^{(63)}$. Amylase and lipase activities were measured, as described by Furné et $a{ }^{(64)}$. AKP, $\mathrm{Na}^{+} / \mathrm{K}^{+}$-ATPase, $\gamma$-glutamyl transpeptidase $(\gamma$-GT) and CK activities in the intestine were determined according to Bessey et al. ${ }^{(65)}$, McCormick $^{(66)}$, Bauermeister et $a{ }^{(67)}$ and Tanzer \& Gilvarg ${ }^{(68)}$, respectively. The intestinal content was extruded for estimating the counts of Lactobacillus, E. coli and Aeromonas using standard techniques, as described by Refstie et $a l .{ }^{(69)}$.

\section{Analysis of target of rapamycin and elF4E-binding protein gene expression in muscle, hepatopancreas and intestine}

Total RNA was extracted from muscle, hepatopancreas, proximal-intestine (PI), mid-intestine (MI) and distal intestine (DI) using an RNAiso plus kit (Takara, Dalian, Liaoning, China). The quality of total RNA was judged by spectrophotometry at 260 and $280 \mathrm{~nm}$. Subsequently, complementary DNA was synthesised using a PrimeScript ${ }^{\mathrm{TM}}$ RT reagent Kit (Takara), according to the manufacturer's instructions. Briefly, oligo dT primers $(50 \mu \mathrm{m})$ were used to reverse transcribe respective 
Table 2. Real-time PCR primer sequences

\begin{tabular}{lll}
\hline Name & Sequences of primers & bp \\
\hline TOR & & \\
$\quad$ Forward & 5'-ATC ATA CGC ATC CAG TCC ATT G-3' $^{\prime}$ & 22 \\
$\quad$ Reverse & 5'-GGT CAT TAG CCA GTA GAG TGT TC-3' $^{\prime}$ & 23 \\
4E-BP & & \\
Forward & 5'-GCT ACC TCA CGA CTA TTG C-3' $^{\prime}$ & 19 \\
$\quad$ Reverse & $5^{\prime}$-TTC TTG CTT GTC ACT CCT G-3' & 19 \\
3-Actin & & \\
Forward & $5^{\prime}$-CGT GAT GGA CTC TGG TGA TG-3' & 20 \\
Reverse & $5^{\prime}$-TCG GCT GTG GTG GTG AAG-3' & 18 \\
\hline
\end{tabular}

TOR, target of rapamycin; 4E-BP, elF4E-binding protein.

RNA in the presence of PrimeScript ${ }^{\mathrm{TM}}$ RT enzyme mix I, $5 \times$ PrimeScript $^{\mathrm{TM}}$ buffer, random 6 mers $(100 \mu \mathrm{M})$ and RNasefree distilled water at $37^{\circ} \mathrm{C}$ for $15 \mathrm{~min}$, following inactivation at $85^{\circ} \mathrm{C}$ for $5 \mathrm{~s}$. Specific primers for $T O R$ and $4 E-B P$ genes were designed with Primer Premier software (Premier Biosoft International, Palo Alto, CA, USA) according to sequences of Jian carp (Genbank accession no. FJ899680 and HQ010440, respectively) cloned in our laboratory. Real-time PCR were performed for TOR and 4E-BP according to standard protocols with the primers indicated in Table 2 . Briefly, complementary DNA $(2 \mu \mathrm{l})$ was reacted with forward and reverse primers, SYBR Premix Ex Taq $^{\text {TM }}$ II $(2 \times ; 7.5 \mu l$; Takara $)$ and RNasefree distilled water in a $15 \mu \mathrm{l}$ final reaction volume. PCR were performed using a Chromo $4^{\mathrm{TM}}$ continuous fluorescence detector (Bio-Rad, Hercules, CA, USA). The thermocycling conditions for TOR and 4E-BP were the following: forty cycles at $95^{\circ} \mathrm{C}$ for $10 \mathrm{~s}, 95^{\circ} \mathrm{C}$ for $5 \mathrm{~s}, 60^{\circ} \mathrm{C}$ for $53 \mathrm{~s}$ and $95^{\circ} \mathrm{C}$ for $10 \mathrm{~s}, 95^{\circ} \mathrm{C}$ for $5 \mathrm{~s}, 59.5^{\circ} \mathrm{C}$ for $30 \mathrm{~s}$, respectively. The expression levels of the $T O R$ and $4 E-B P$ genes were normalised to the expression levels of a housekeeping common carp gene, $\beta$-actin. Each assay was performed with five replications. The concentration of the target gene was calculated based on the threshold cycle number (cycle threshold). The cycle threshold for each sample was determined by using MJ Opticon Monitor Software (version 3.1; Bio-Rad, Hemel Hempstead, Herts, UK). In addition, the complementary DNA concentration in each sample was determined according to gene-specific standard curves. Standard curves were generated for both target and endogenous control genes based on 10-fold serial dilutions. All standard curves exhibited correlation coefficients higher than 0.99, and the corresponding real-time PCR efficiencies ranged between $0 \cdot 90$ and $1 \cdot 10$.

\section{Calculations and statistical analysis}

Data on initial body weight, final body weight, FI, proximate composition of feed and carcass, hepatopancreas and intestine weight, intestine and body length, and hepatopancreas and intestine protein were used to calculate the following parameters:

Feed efficiency $(\mathrm{FE})=(\mathrm{g}$ weight gain $/ \mathrm{g}$ FI $) \times 100$;

Specific growth rate $=((\ln$ final weight $-\ln$ initial weight $) /$ number of d) $\times 100$;

Protein efficiency ratio $=\mathrm{g}$ weight gain $/ \mathrm{g}$ protein intake;
Protein retention value $(\mathrm{PRV})=($ final total body protein initial body protein)/total protein intake;

Ash retention value $=\mathrm{g}$ fish ash gain $/ \mathrm{g}$ ash intake;

Intestosomatic index (ISI) $=$ (g wet intestine weight $/ \mathrm{g}$ wet body weight) $\times 100$;

Hepatosomatic index $=$ (g wet hepatopancreas weight $/ \mathrm{g}$ wet body weight $) \times 100$;

Relative gut length $(\mathrm{RGL})=$ digestive tract length $(\mathrm{cm}) /$ total body length $(\mathrm{cm})$;

Intestine protein content $=$ (g intestine protein $/ \mathrm{g}$ wet intestine weight) $\times 100$;

Hepatopancreas protein content $=(\mathrm{g}$ hepatopancreas protein $/ g$ wet hepatopancreas weight $) \times 100$;

All data were subjected to a one-way ANOVA. Differences between the treatment mean values were determined using a Duncan's multiple-range test at a $P<0.05$ level of significance. A quadratic regression model was used to determine the optimal level of dietary arginine.

\section{Results}

\section{Growth performance}

Dietary arginine did not have a significant effect on the survival rate $(>97 \%)$ of juvenile Jian carp. No pathological signs were observed during the trial. As shown in Table 3, the lowest specific growth rate (SGR) was found in fish fed with the basal diet $(P<0 \cdot 05)$. FI significantly increased with higher levels of dietary arginine up to $16 \cdot 1 \mathrm{~g}$ arginine/kg diet and decreased thereafter $(P<0.05$; Table 3). Quadratic regression analysis showed that SGR and FI increased with increasing levels of dietary arginine. The following equations were obtained for SGR and for FI, respectively: $Y=2.531+0.0862 x-0.0024 x^{2}, \quad R^{2} 0.930, \quad P<0.05$ and $Y=35.256+2.5749 x-0.0762 x^{2}, R^{2} 0.942, P<0.05$. On the basis of the aforementioned quadratic regression equation, the arginine requirement for the juvenile carp was estimated to be $18.0 \mathrm{~g} / \mathrm{kg}$ diet, corresponding to $55.0 \mathrm{~g} / \mathrm{kg}$ dietary protein (Fig. 1). Values of FE, protein efficiency ratio and PRV were the highest for fish fed with diets containing $18.5 \mathrm{~g}$ arginine/ $\mathrm{kg}$ diet and the lowest for fish fed with diets containing $12.7 \mathrm{~g}$ arginine $/ \mathrm{kg}$ diet $(P<0.05)$. The ash retention value increased with dietary arginine levels up to $18.5 \mathrm{~g} / \mathrm{kg}$ diet $(P<0.05)$, whereas higher arginine levels resulted in a plateau-like response $(P>0 \cdot 05)$. The following equations were obtained for PRV and for ash retention value, respectively: $Y=26.646+0.7721 x-0.0198 x^{2}, R^{2} 0.699$ and $Y=30.496+$ $0.5574 x-0.0129 x^{2}, R^{2} 0.738$.

\section{Glutamate oxaloacetate transaminase and glutamate pyruvate transaminase activities in muscle and hepatopancreas}

GOT and GPT activities in muscle and hepatopancreas, as well as plasma ammonia content (PAC) are given in Table 4. GOT activities in muscle and hepatopancreas were the highest for fish fed with diets containing $18.5 \mathrm{~g}$ arginine/ $\mathrm{kg}$ diet and the lowest for fish fed with the basal diet 
Table 3. Growth, feed intake (FI) and conversion efficiency of juvenile Jian carp (Cyprinus carpio var. Jian) fed with diets containing graded levels of dietary arginine

(Mean values with their standard errors for four replicates)

\begin{tabular}{|c|c|c|c|c|c|c|c|c|c|c|c|c|}
\hline \multirow{2}{*}{$\begin{array}{l}\text { Dietary Arg } \\
\text { levels }(\mathrm{g} / \mathrm{kg}) \ldots\end{array}$} & \multicolumn{2}{|c|}{9.8} & \multicolumn{2}{|c|}{$12 \cdot 7$} & \multicolumn{2}{|c|}{$16 \cdot 1$} & \multicolumn{2}{|c|}{$18 \cdot 5$} & \multicolumn{2}{|c|}{21.9} & \multicolumn{2}{|c|}{24.5} \\
\hline & Mean & SE & Mean & SE & Mean & SE & Mean & SE & Mean & SE & Mean & SE \\
\hline IBW (g) & $6 \cdot 34$ & 0.017 & 6.34 & 0.009 & $6 \cdot 35$ & 0.023 & 6.33 & 0.008 & $6 \cdot 31$ & 0.009 & $6 \cdot 34$ & 0.004 \\
\hline FBW (g) & $46 \cdot 2^{a}$ & 0.47 & $47 \cdot 7^{a}$ & 0.98 & $50 \cdot 7^{\mathrm{b}}$ & 0.72 & $50 \cdot 8^{\mathrm{b}}$ & 0.52 & $48 \cdot 7^{\mathrm{a}, \mathrm{b}}$ & 0.85 & $47 \cdot 0^{\mathrm{a}}$ & 1.37 \\
\hline SGR (\%/d) & $3 \cdot 155^{a}$ & 0.016 & $3.203^{a}$ & 0.033 & $3 \cdot 297^{b}$ & 0.020 & $3.304^{\mathrm{b}}$ & 0.017 & $3 \cdot 243^{a, b}$ & 0.028 & $3.179^{a}$ & 0.046 \\
\hline $\mathrm{FI}(\mathrm{g})$ & $52 \cdot 9^{\mathrm{a}}$ & 0.21 & $56.0^{\mathrm{b}}$ & 0.63 & $57.5^{\mathrm{c}}$ & 0.43 & $56 \cdot 1^{\mathrm{b}}$ & 0.33 & $55.0^{\mathrm{b}}$ & 0.48 & $52 \cdot 8^{\mathrm{a}}$ & 0.36 \\
\hline $\mathrm{FE}$ & $75 \cdot 4^{\mathrm{a}, \mathrm{b}}$ & 0.65 & $73 \cdot 9^{\mathrm{a}}$ & 0.97 & $77 \cdot 2^{\mathrm{a}, \mathrm{b}}$ & 0.67 & $79 \cdot 3^{b}$ & 0.72 & $77 \cdot 2^{a, b}$ & 1.17 & $77 \cdot 0^{a, b}$ & $2 \cdot 18$ \\
\hline PER & $2 \cdot 298^{a, b}$ & 0.020 & $2 \cdot 252^{\mathrm{a}}$ & 0.030 & $2 \cdot 352^{\mathrm{a}, \mathrm{b}}$ & 0.020 & $2 \cdot 416^{\mathrm{b}}$ & 0.022 & $2 \cdot 353^{a, b}$ & 0.036 & $2 \cdot 348^{a, b}$ & 0.067 \\
\hline PRV & $32 \cdot 7^{\mathrm{a}}$ & 0.28 & $32 \cdot 5^{\mathrm{a}}$ & 0.42 & $34 \cdot 0^{\mathrm{a}, \mathrm{b}}$ & 0.30 & $34.8^{\mathrm{b}}$ & 0.31 & $33 \cdot 8^{a, b}$ & 0.51 & $33 \cdot 7^{\mathrm{a}, \mathrm{b}}$ & 0.95 \\
\hline ARV & $35.2^{\mathrm{a}}$ & 0.31 & $35 \cdot 2^{\mathrm{a}}$ & 0.47 & $36 \cdot 1^{a, b}$ & 0.33 & $37.6^{\mathrm{b}}$ & 0.34 & $36 \cdot 7^{\mathrm{a}, \mathrm{b}}$ & 0.56 & $36 \cdot 8^{a, b}$ & 1.06 \\
\hline
\end{tabular}

IBW, initial body weight; FBW, final body weight; SGR, specific growth rate; FE, feed efficiency; PER, protein efficiency ratio; PRV, protein retention value; ARV, ash retention value. ${ }^{a, b}$ Mean values within a row with unlike superscript letters were significantly different $(P<0.05)$.

$(P<0.05)$. In addition, GOT activity in muscle showed a quadratic response to increasing dietary arginine concentrations $\left(Y=-1119 \cdot 5+431 \cdot 29 x-11 \cdot 778 x^{2}, R^{2} 0 \cdot 882, P<0.05\right)$. GPT activities in muscle and hepatopancreas were the highest for fish fed with diets containing $16 \cdot 1 \mathrm{~g}$ arginine $/ \mathrm{kg}$ diet $(P<0.05)$. PAC was the lowest for fish fed with diets containing $18.5 \mathrm{~g}$ arginine/ $\mathrm{kg}$ diet $(P<0.05)$.

\section{Hepatopancreas and intestine growth and development}

As shown in Table 5, the hepatopancreas weight was the lowest for fish fed with the basal diet, followed by 24.5 and $21.9 \mathrm{~g}$ arginine $/ \mathrm{kg}$ diet, and it was the highest for fish fed with diets containing $12.7 \mathrm{~g}$ arginine/ $\mathrm{kg}$ diet $(P<0.05)$. The hepatosomatic index and protein content were the highest for fish fed with diets containing 12.7 and $18.5 \mathrm{~g}$ arginine $/ \mathrm{kg}$ $\operatorname{diet}(P<0 \cdot 05)$, respectively. The following equations were obtained for hepatopancreas weight and for hepatopancreas protein content, respectively: $Y=0.4010+0.1535 x-0.0045 x^{2}$, $R^{2} 0.756$ and $Y=0.7226+0.0325 x-0.0007 x^{2}, R^{2} 0.810$. Intestine length significantly increased with increasing dietary arginine levels up to $12.7 \mathrm{~g}$ arginine $/ \mathrm{kg}$ diet $(P<0.05)$, and there were no differences between 12.7 and $21.9 \mathrm{~g}$ arginine/ $\mathrm{kg}$ diet levels $(P>0 \cdot 05)$. The RGL showed a non-significant tendency towards an improvement of dietary arginine levels above $12.7 \mathrm{~g}$ arginine $/ \mathrm{kg}$ diet $(P>0.05)$, with the only exception of fish fed with $18.5 \mathrm{~g}$ arginine $/ \mathrm{kg}$ diet. Similar patterns were found for intestine weight. The ISI was the highest for fish fed with the basal diet and the lowest for fish fed with a diet containing $21.9 \mathrm{~g}$ arginine/ $\mathrm{kg} \operatorname{diet}(P<0.05)$. The intestine protein content was the highest for fish fed with a diet containing $16 \cdot 1 \mathrm{~g}$ arginine $/ \mathrm{kg}$ diet $(P<0.05)$ and the lowest for fish fed with the basal diet. Quadratic regression analysis showed that intestine length, RGL, intestine weight and ISI increased or decreased with higher levels of dietary arginine. The following equations were obtained for intestine length, RGL, intestine weight and ISI, respectively: $Y=6.0540+$ $1.6892 x-0.0482 x^{2}, R^{2} 0 \cdot 811 ; Y=103 \cdot 15+6.6738 x-0.1953 x^{2}$, $R^{2} 0.777 ; \quad Y=0.7446+0.1236 x-0.0037 x^{2}, R^{2} 0.757 ;$ and $Y=4.8646-0 \cdot 1580 x+0.0037 x^{2}, R^{2} 0.9369, P<0 \cdot 05$.

\section{Hepatopancreas and intestine enzyme activities}

The trypsin activity in the intestine was compared across dietary treatments (Table 6). The activity was responsive to dietary arginine by increasing with graded levels of arginine up to $16.1 \mathrm{~g} / \mathrm{kg}$ diet $(P<0.05)$, and there was no difference between 16.1 and $18.5 \mathrm{~g} / \mathrm{kg}$ diet $(P>0.05)$, and was positively related to the activity of the hepatopancreas $(r+0.939$, $P<0.01)$. Similarly, the chymotrypsin activity in the hepatopancreas was the highest for fish fed with a diet containing $16 \cdot 1 \mathrm{~g}$ arginine $/ \mathrm{kg}$ diet and the lowest for fish fed with the diet containing $24.5 \mathrm{~g}$ arginine $/ \mathrm{kg}$ diet $(P<0 \cdot 05$; Table 6). The chymotrypsin activity in the intestine was the highest for fish fed with diets containing $18.5 \mathrm{~g}$ arginine $/ \mathrm{kg}$ diet $(P<0.05)$. Lipase activities in hepatopancreas showed a nonsignificant tendency towards the improvement of dietary arginine levels ( $P>0.05)$, with the only exception for fish fed with $24.5 \mathrm{~g}$ arginine $/ \mathrm{kg}$ diet, exhibiting significantly lower values $(P<0.05)$. In the intestine, lipase activities increased with higher levels of dietary arginine up to $18.5 \mathrm{~g}$ arginine $/ \mathrm{kg}$ diet $(P<0.05)$ and decreased thereafter. The following equations were obtained for trypsin activities and for lipase activities, respectively, in the hepatopancreas: $Y=1 \cdot 4137+0 \cdot 2803 x-$ $0.0081 x^{2}, R^{2} 0.8836, \quad P<0.05$ and $Y=1098 \cdot 3+98.428 x-$ $3.0784 x^{2}, R^{2} 0 \cdot 858, P=0 \cdot 05$. Amylase activities in the hepatopancreas increased with higher levels of dietary arginine up to

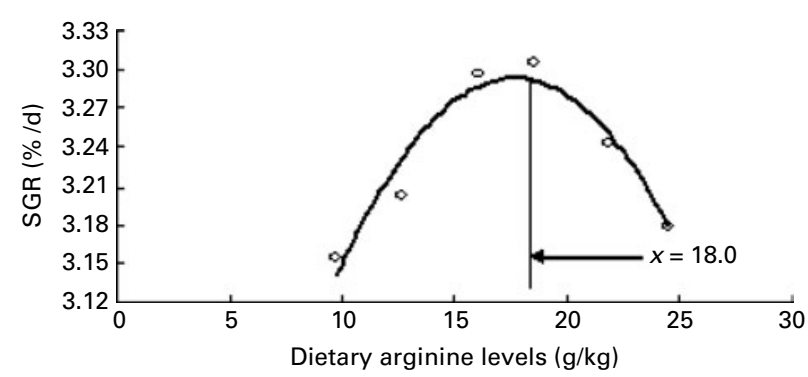

Fig. 1. Quadratic regression analysis of specific growth rate (SGR, \%/d) according to dietary arginine levels $\left(y=-0.0024 x^{2}+0.0862 x+2.531\right.$, $R^{2} 0.930$ ). Each point represents the mean of four groups of Jian carp with fifty fish per group. Arginine requirement estimated from SGR was $18.0 \mathrm{~g} / \mathrm{kg}$ diet. 
Table 4. Glutamate-oxaloacetate transaminase and glutamate-pyruvate transaminase activities in muscle and hepatopancreas; plasma ammonia content of juvenile Jian carp (Cyprinus carpio var. Jian) fed with diets containing graded levels of arginine

(Mean values with their standard errors for four replicates)

\begin{tabular}{|c|c|c|c|c|c|c|c|c|c|c|c|c|}
\hline \multirow{2}{*}{$\begin{array}{l}\text { Dietary Arg } \\
\text { levels }(\mathrm{g} / \mathrm{kg}) \ldots\end{array}$} & \multicolumn{2}{|c|}{$9 \cdot 8$} & \multicolumn{2}{|c|}{$12 \cdot 7$} & \multicolumn{2}{|c|}{$16 \cdot 1$} & \multicolumn{2}{|c|}{18.5} & \multicolumn{2}{|c|}{$21 \cdot 9$} & \multicolumn{2}{|c|}{24.5} \\
\hline & Mean & SE & Mean & SE & Mean & SE & Mean & SE & Mean & SE & Mean & SE \\
\hline \multicolumn{13}{|c|}{ Glu-oxaloacetate transaminase activities ( $\mathrm{U} / \mathrm{g}$ tissue) } \\
\hline Muscle & $2015^{\mathrm{a}}$ & $42 \cdot 9$ & $2407^{\mathrm{b}, \mathrm{c}}$ & $81 \cdot 7$ & $2657^{\mathrm{c}}$ & $75 \cdot 2$ & $3032^{d}$ & 102 & $2586^{\mathrm{b}, \mathrm{c}}$ & 109 & $2390^{\mathrm{b}}$ & $71 \cdot 3$ \\
\hline Hepatopancreas & $1766^{\mathrm{a}}$ & $66 \cdot 3$ & $1980^{b, c}$ & $60 \cdot 2$ & $2033^{c}$ & $55 \cdot 3$ & $2639^{d}$ & $35 \cdot 7$ & $1997^{\mathrm{C}}$ & $45 \cdot 1$ & $1819^{\mathrm{a}, \mathrm{b}}$ & $67 \cdot 7$ \\
\hline \multicolumn{13}{|c|}{ Glu-pyruvate transaminase activities (U/g tissue) } \\
\hline Muscle & $455^{\mathrm{a}}$ & $9 \cdot 31$ & $522^{b, c}$ & $18 \cdot 0$ & $612^{d}$ & $18 \cdot 2$ & $552^{\mathrm{C}}$ & 7.46 & $514^{\mathrm{b}, \mathrm{c}}$ & $16 \cdot 3$ & $492^{a, b}$ & 9.95 \\
\hline Hepatopancreas & $574^{\mathrm{b}}$ & 9.51 & $604^{b, c}$ & $11 \cdot 7$ & $642^{\mathrm{C}}$ & $21 \cdot 8$ & $612^{\mathrm{b}, \mathrm{c}}$ & $18 \cdot 2$ & $567^{b}$ & $18 \cdot 0$ & $507^{a}$ & $17 \cdot 9$ \\
\hline \multicolumn{13}{|c|}{ Ammonia content $(\mu \mathrm{mol} / \mathrm{l})$} \\
\hline Plasma & $233^{d}$ & $4 \cdot 80$ & $122^{b}$ & 3.92 & $110^{a, b}$ & $4 \cdot 80$ & $102^{\mathrm{a}}$ & 7.33 & $188^{\mathrm{C}}$ & $4 \cdot 80$ & $192^{\mathrm{C}}$ & $7 \cdot 33$ \\
\hline
\end{tabular}

a,b,c,d Mean values within a row with unlike superscript letters were significantly different $(P<0.05)$.

$16 \cdot 1 \mathrm{~g}$ arginine $/ \mathrm{kg}$ diet $(P<0 \cdot 05)$. No significant differences were found in intestinal amylase activities between dietary treatments $(P>0 \cdot 05)$.

As shown in Table 6, folds height in the PI was the highest for fish fed with a diet containing $18.5 \mathrm{~g}$ arginine $/ \mathrm{kg}$ diet $(P<0.05)$; the height values decreased with diets containing $16 \cdot 1,21 \cdot 9, \quad 12.7$ and $24.5 \mathrm{~g}$ arginine $/ \mathrm{kg}$ diet; finally, the lowest value occurred in fish fed with the basal diet $(P<0.05)$. The highest folds height in MI and DI were obtained for fish fed with a diet containing $16 \cdot 1 \mathrm{~g}$ arginine/ $\mathrm{kg}$ diet $(P<0.05)$. In addition, $\mathrm{Na}^{+} / \mathrm{K}^{+}$-ATPase activity in the PI and DI increased with higher levels of dietary arginine up to $16 \cdot 1 \mathrm{~g}$ arginine $/ \mathrm{kg}$ diet, and the lowest activities occurred in fish fed with a diet containing $24.5 \mathrm{~g}$ arginine $/ \mathrm{kg}$ diet (Table 6). In the MI, the $\mathrm{Na}^{+} / \mathrm{K}^{+}$-ATPase activity was the highest for fish fed with a diet containing $18.5 \mathrm{~g}$ arginine $/ \mathrm{kg}$ diet $(P<0.05)$. In the $\mathrm{PI}$, the $\mathrm{Na}^{+} / \mathrm{K}^{+}$-ATPase activity showed a quadratic response to increasing dietary arginine concentrations $\left(Y=-778.33+121 \cdot 28 x-3.551 x^{2}\right.$, $R^{2}$ 0.953, $\left.P<0.05\right)$. Intestinal AKP activities increased as dietary arginine levels rose up to $16 \cdot 1 \mathrm{~g}$ arginine $/ \mathrm{kg}$ diet $(P<0.05)$. SGR was positively related to AKP activities in the PI $(r+0.921, P<0.05)$. The following equations were obtained for AKP activities in the PI and MI, respectively: $Y=-39.976+7.6209 x-0.2240 x^{2}, \quad R^{2} \quad 0.998, \quad P<0.05$ and $Y=-33.781+6.5985 x-0.1914 x^{2}, R^{2} 0.920, P<0.05$.
Similar patterns were found in intestinal $\gamma$-GT activity. The following equations were obtained for $\gamma$-GT activities in the PI, MI and DI, respectively: $Y=-10.901+2 \cdot 800 x-0.0833 x^{2}$, $R^{2}$ 0.944, $P<0.05 ; \quad Y=-4.897+1.5857 x-0.0450 x^{2}, \quad R^{2}$ $0.973, P<0.01 ;$ and $Y=-14.819+4.3235 x-0.1299 x^{2}, R^{2}$ $0.884, P<0.05$. CK activities in the whole intestine significantly increased up to $18.5 \mathrm{~g}$ arginine $/ \mathrm{kg}$ diet and showed quadratic responses to increasing levels of dietary arginine $\left(Y=-487 \cdot 81+91 \cdot 386 x-2 \cdot 5196 x^{2}, R^{2} 0 \cdot 855\right)$.

\section{Intestinal microflora population}

As shown in Table 7, Aeromonas and E. coli were the lowest for fish fed with a diet containing $16.1 \mathrm{~g}$ arginine $/ \mathrm{kg}$ diet and the highest for fish fed with the basal diet $(P<0.05)$. Lactobacillus populations significantly increased with higher levels of dietary arginine up to $16.1 \mathrm{~g} / \mathrm{kg}$ diet $(P<0.05)$, and there were no differences between the $16 \cdot 1$ and $21.9 \mathrm{~g} / \mathrm{kg}$ diet levels $(P>0.05)$. Quadratic regression analysis showed that the populations of intestinal microbiota increased or decreased with higher levels of dietary arginine. The following equations were obtained for Aeromonas, E. coli and Lactobacillus, respectively: $Y=10 \cdot 206-0 \cdot 2213 x+0.0063 x^{2}$, $R^{2} 0.992, P<0.01 ; Y=10.343-0.3479 x+0.0100 x^{2}, R^{2} 0.938$, $P<0.05$; and $Y=1.6435+0.5783 x-0.0150 x^{2}, \quad R^{2} \quad 0.972$, $P<0 \cdot 01$

Table 5. Hepatopancreas and intestinal activities of Jian carp (Cyprinus carpio var. Jian) fed with diets containing graded levels of dietary arginine (Mean values with their standard errors for four replicates)

\begin{tabular}{|c|c|c|c|c|c|c|c|c|c|c|c|c|}
\hline \multirow{2}{*}{$\begin{array}{l}\text { Dietary Arg } \\
\text { levels }(\mathrm{g} / \mathrm{kg}) \ldots\end{array}$} & \multicolumn{2}{|c|}{$9 \cdot 8$} & \multicolumn{2}{|c|}{$12 \cdot 7$} & \multicolumn{2}{|c|}{$16 \cdot 1$} & \multicolumn{2}{|c|}{$18 \cdot 5$} & \multicolumn{2}{|c|}{21.9} & \multicolumn{2}{|c|}{24.5} \\
\hline & Mean & SE & Mean & SE & Mean & SE & Mean & SE & Mean & SE & Mean & SE \\
\hline \multicolumn{13}{|l|}{ Hepatopancreas } \\
\hline Weight $(\mathrm{g})$ & $1.42^{\mathrm{a}}$ & 0.08 & $1 \cdot 74^{\mathrm{c}}$ & 0.05 & $1.68^{c}$ & 0.06 & $1.68^{c}$ & 0.04 & $1 \cdot 60^{\mathrm{b}, \mathrm{c}}$ & 0.06 & $1 \cdot 50^{a, b}$ & 0.05 \\
\hline Index & $3 \cdot 33^{a, b}$ & 0.13 & $3.46^{b}$ & 0.15 & $3.01^{a}$ & 0.12 & $3 \cdot 18^{a, b}$ & 0.10 & $3 \cdot 11^{a, b}$ & 0.16 & $3 \cdot 04^{a}$ & 0.13 \\
\hline $\begin{array}{l}\text { Protein content } \\
\text { Intestine }\end{array}$ & $0.98^{a}$ & 0.04 & $1 \cdot 04^{a, b, c}$ & 0.04 & $1 \cdot 03^{a, b}$ & 0.03 & $1 \cdot 14^{\mathrm{c}}$ & 0.04 & $1 \cdot 12^{b, c}$ & 0.02 & $1 \cdot 12^{b, c}$ & 0.03 \\
\hline Length (cm) & $17 \cdot 5^{\mathrm{a}}$ & 0.35 & $20 \cdot 5^{b, c}$ & 0.68 & $21 \cdot 1^{\mathrm{b}, \mathrm{c}}$ & 0.63 & $20 \cdot 2^{b, c}$ & 0.53 & $19 \cdot 6^{\mathrm{b}, \mathrm{c}}$ & 0.38 & $18 \cdot 9^{b}$ & 0.37 \\
\hline Relative length & $148^{a}$ & $3 \cdot 61$ & $160^{a, b}$ & $4 \cdot 73$ & $158^{a, b}$ & 4.51 & $161^{\mathrm{b}}$ & 3.99 & $153^{a, b}$ & 3.06 & $151^{a, b}$ & $2 \cdot 76$ \\
\hline Weight (g) & $1.57^{\mathrm{a}}$ & 0.07 & $1 \cdot 75^{\mathrm{b}, \mathrm{c}}$ & 0.04 & $1 \cdot 83^{\mathrm{C}}$ & 0.04 & $1 \cdot 73^{\mathrm{b}, \mathrm{c}}$ & 0.06 & $1 \cdot 61^{a, b}$ & 0.04 & $1 \cdot 60^{a, b}$ & 0.03 \\
\hline Index & $3 \cdot 66^{c}$ & 0.09 & $3.48^{\mathrm{b}, \mathrm{c}}$ & 0.14 & $3 \cdot 27^{a, b}$ & 0.09 & $3 \cdot 27^{a, b}$ & 0.13 & $3 \cdot 11^{a}$ & 0.11 & $3 \cdot 27^{a, b}$ & 0.14 \\
\hline Protein content & $1 \cdot 06^{a}$ & 0.03 & $1 \cdot 15^{a, b}$ & 0.05 & $1 \cdot 19^{b}$ & 0.05 & $1 \cdot 17^{a, b}$ & 0.03 & $1 \cdot 08^{a, b}$ & 0.04 & $1 \cdot 13^{\mathrm{a}, \mathrm{b}}$ & 0.04 \\
\hline
\end{tabular}

${ }_{\mathrm{a}, \mathrm{b}, \mathrm{c}}$ Mean values within a row with unlike superscript letters were significantly different $(P<0.05)$. 
Table 6. Enzymatic activities in hepatopancreas and intestine of juvenile Jian carp (Cyprinus carpio var. Jian) fed with diets containing graded levels of dietary arginine

(Mean values with their standard errors for four replicates)

\begin{tabular}{|c|c|c|c|c|c|c|c|c|c|c|c|c|}
\hline \multirow{2}{*}{$\begin{array}{l}\text { Dietary Arg } \\
\text { levels }(\mathrm{g} / \mathrm{kg}) \ldots\end{array}$} & \multicolumn{2}{|c|}{9.8} & \multicolumn{2}{|c|}{$12 \cdot 7$} & \multicolumn{2}{|c|}{$16 \cdot 1$} & \multicolumn{2}{|c|}{18.5} & \multicolumn{2}{|c|}{21.9} & \multicolumn{2}{|c|}{24.5} \\
\hline & Mean & SE & Mean & SE & Mean & SE & Mean & SE & Mean & SE & Mean & SE \\
\hline \multicolumn{13}{|c|}{ Enzymatic activities in hepatopancreas (U/g tissue) } \\
\hline Trypsin & $0.53^{\mathrm{a}}$ & 0.02 & $0.89^{c}$ & 0.03 & $1.00^{\mathrm{d}}$ & 0.02 & $1 \cdot 07^{\mathrm{d}}$ & 0.03 & $0 \cdot 74^{\mathrm{b}}$ & 0.02 & $0.68^{\mathrm{b}}$ & 0.01 \\
\hline Chymotrypsin & $4 \cdot 72^{\mathrm{a}}$ & 0.20 & $4 \cdot 75^{\mathrm{a}}$ & 0.15 & $6 \cdot 11^{\mathrm{c}}$ & 0.17 & $5 \cdot 54^{\mathrm{b}}$ & 0.21 & $5 \cdot 00^{\mathrm{a}}$ & 0.06 & $4 \cdot 67^{a}$ & 0.20 \\
\hline Lipase & $1783^{b}$ & 41.9 & $1837^{\mathrm{b}}$ & $34 \cdot 2$ & $1838^{\mathrm{b}}$ & 34.2 & $1919^{b}$ & 27.0 & $1784^{b}$ & 41.9 & $1648^{a}$ & $65 \cdot 1$ \\
\hline Amylase & $1113^{a}$ & 23.0 & $1242^{b, c}$ & 34.6 & $1275^{\mathrm{c}}$ & $15 \cdot 8$ & $1271^{c}$ & 31.2 & $1263^{a, b}$ & 30.8 & $1200^{\mathrm{b}, \mathrm{c}}$ & 28.9 \\
\hline \multicolumn{13}{|c|}{ Enzymatic activities in intestine (U/g tissue) } \\
\hline Trypsin & $1.29^{\mathrm{a}}$ & 0.07 & $1.47^{\mathrm{b}}$ & 0.05 & $1 \cdot 72^{\mathrm{c}}$ & 0.05 & $1.72^{\mathrm{C}}$ & 0.07 & $1 \cdot 35^{\mathrm{a}, \mathrm{b}}$ & 0.05 & $1.40^{\mathrm{a}, \mathrm{b}}$ & 0.04 \\
\hline Chymotrypsin & $2.53^{\mathrm{a}}$ & 0.11 & $2 \cdot 86^{a, b}$ & $0 \cdot 10$ & $2 \cdot 86^{a, b}$ & 0.11 & $4 \cdot 31^{\mathrm{c}}$ & 0.16 & $2.92^{\mathrm{b}}$ & 0.06 & $2.53^{\mathrm{a}}$ & 0.07 \\
\hline Lipase & $1513^{a}$ & $68 \cdot 4$ & $1594^{a, b, c}$ & 49.8 & $1730^{\mathrm{b}, \mathrm{c}}$ & 54.0 & $1757^{c}$ & 49.8 & $1648^{a, b, c}$ & 49.8 & $1567^{a, b}$ & $54 \cdot 0$ \\
\hline \multirow{2}{*}{\multicolumn{13}{|c|}{ Folds height $(\mu \mathrm{m})$}} \\
\hline & & & & & & & & & & & & \\
\hline Proximal & $439^{a}$ & 2.51 & $470^{c}$ & 3.35 & $488^{d}$ & $2 \cdot 46$ & $491^{d}$ & 4.78 & $478^{\mathrm{c}}$ & $3 \cdot 27$ & $459^{b}$ & 3.73 \\
\hline Mid & $282^{a}$ & 4.77 & $298^{\mathrm{b}}$ & 3.00 & $309^{c}$ & 3.17 & $289^{a, b}$ & 3.45 & $285^{\mathrm{a}}$ & 3.24 & $287^{\mathrm{a}}$ & 3.07 \\
\hline Distal & $265^{a}$ & 1.70 & $283^{b}$ & 4.39 & $294^{\mathrm{C}}$ & 2.96 & $286^{\mathrm{b}, \mathrm{c}}$ & 3.72 & $285^{\mathrm{b}, \mathrm{c}}$ & 3.42 & $269^{a}$ & 1.78 \\
\hline \multicolumn{13}{|c|}{$\mathrm{Na}^{+}, \mathrm{K}^{+}$-ATPase activities in intestine ( $\mu$ mol $\mathrm{P}$ released $\mathrm{g} /$ tissue per $\mathrm{h}$ ) } \\
\hline Proximal & $83 \cdot 6^{\mathrm{b}}$ & $2 \cdot 14$ & $157^{\mathrm{c}}$ & $5 \cdot 62$ & $267^{d}$ & 6.09 & $265^{d}$ & $5 \cdot 71$ & $163^{\mathrm{c}}$ & 6.09 & $63 \cdot 2^{\mathrm{a}}$ & $2 \cdot 04$ \\
\hline Mid & $115^{\mathrm{a}}$ & 1.58 & $124^{\mathrm{a}}$ & 4.04 & $209^{c}$ & $7 \cdot 38$ & $252^{d}$ & $6 \cdot 72$ & $184^{\mathrm{b}}$ & $7 \cdot 18$ & $182^{\mathrm{b}}$ & $6 \cdot 20$ \\
\hline Distal & $124^{\mathrm{b}, \mathrm{c}}$ & 4.53 & $132^{c}$ & 4.64 & $166^{\mathrm{d}}$ & 6.36 & $174^{\mathrm{d}}$ & $6 \cdot 28$ & $113^{\mathrm{a}}$ & 2.65 & $105^{\mathrm{a}}$ & 4.03 \\
\hline \multicolumn{13}{|c|}{ Alkaline phosphatase activities in intestine ( $\mathrm{mmol}$ nitrophenol released g/tissue per $\mathrm{h}$ ) } \\
\hline Proximal & $13 \cdot 2^{\mathrm{a}}$ & 0.31 & $20 \cdot 8^{\mathrm{c}}$ & 0.40 & $24 \cdot 2^{d}$ & 0.54 & $24 \cdot 7^{\mathrm{d}}$ & 0.33 & $19 \cdot 5^{\mathrm{b}}$ & 0.56 & $12 \cdot 2^{\mathrm{a}}$ & 0.48 \\
\hline Mid & $13 \cdot 7^{\mathrm{a}}$ & 0.42 & $16 \cdot 7^{\mathrm{b}}$ & 0.71 & $23.5^{\mathrm{d}}$ & 0.43 & $23 \cdot 8^{d}$ & 0.60 & $18 \cdot 8^{c}$ & 0.48 & $12 \cdot 7^{\mathrm{a}}$ & 0.49 \\
\hline Distal & $5 \cdot 67^{a}$ & 0.21 & $7 \cdot 50^{\mathrm{b}}$ & 0.22 & $7 \cdot 83^{c}$ & 0.17 & $9 \cdot 83^{\mathrm{C}}$ & 0.31 & $7 \cdot 33^{\mathrm{b}}$ & 0.21 & $7 \cdot 50^{\mathrm{b}}$ & 0.22 \\
\hline \multicolumn{13}{|c|}{$\gamma$-Glutamyl transpeptidase activities in intestine (mmol 5-amino-2-nitrobenzoate released g/tissue per min) } \\
\hline Proximal & $8 \cdot 63^{b, c}$ & 0.15 & $10 \cdot 9^{\mathrm{c}}$ & 0.33 & $12 \cdot 8^{\mathrm{d}}$ & 0.19 & $12 \cdot 9^{\mathrm{d}}$ & 0.41 & $9 \cdot 67^{b}$ & 0.29 & $8 \cdot 07^{a}$ & 0.08 \\
\hline Mid & $6 \cdot 28^{\mathrm{a}}$ & 0.17 & $8 \cdot 07^{\mathrm{C}}$ & 0.29 & $8 \cdot 79^{\mathrm{d}}$ & 0.10 & $9 \cdot 28^{d}$ & 0.30 & $8 \cdot 00^{c}$ & 0.27 & $7 \cdot 02^{b}$ & 0.19 \\
\hline Distal & $15 \cdot 5^{\mathrm{a}, \mathrm{b}}$ & 0.45 & $18 \cdot 0^{\mathrm{c}}$ & 0.46 & $21.6^{d}$ & 1.16 & $22 \cdot 0^{\mathrm{d}}$ & 0.71 & $15 \cdot 9^{b}$ & 0.53 & $13 \cdot 8^{a}$ & 0.34 \\
\hline \multicolumn{13}{|c|}{ Creatine kinase activities ( $\mu$ mol $P$ released g/tissue per $h$ ) } \\
\hline Intestine & $183^{\mathrm{a}}$ & $4 \cdot 30$ & $234^{\mathrm{b}}$ & 2.44 & $322^{d}$ & 7.02 & $383^{\mathrm{e}}$ & 8.46 & $284^{c}$ & 4.63 & $241^{b}$ & 3.75 \\
\hline
\end{tabular}

a,b,c,d,e Mean values within a row with unlike superscript letters were significantly different $(P<0.05)$.

Relative expression of target of rapamycin and elF4Ebinding protein in muscle, hepatopancreas and intestine

TOR mRNA levels were the highest for fish fed with a diet containing $16 \cdot 1 \mathrm{~g}$ arginine/kg diet in muscle and hepatopancreas $(P<0.05$; Fig. 2$)$. Patterns of TOR mRNA in the PI and MI were opposite compared with those in the muscle and hepatopancreas (Fig. 2). TOR mRNA levels in the DI increased with higher levels of dietary arginine up to $12 \cdot 7 \mathrm{~g} / \mathrm{kg}$ diet (Fig. 2; $P<0.05$ ), whereas no significant differences were found with a further increase in dietary arginine concentration $(P>0.05)$. In the hepatopancreas, $4 \mathrm{E}-\mathrm{BP}$ mRNA levels were the lowest for fish fed with a diet containing $16.1 \mathrm{~g}$ arginine/ $\mathrm{kg}$ diet and the highest for fish fed with a diet containing $24.5 \mathrm{~g}$ arginine $/ \mathrm{kg}$ diet (Fig. 3; $P<0.05$ ). The levels of $4 \mathrm{E}-\mathrm{BP}$
mRNA in the PI slightly increased with dietary arginine levels up to $16.1 \mathrm{~g} / \mathrm{kg}$ diet (Fig. 3; $P>0.05$ ); the highest values were obtained in fish fed with a diet containing $18.5 \mathrm{~g}$ arginine $/ \mathrm{kg}$ diet and then decreased. In the MI, $4 \mathrm{E}-\mathrm{BP}$ mRNA levels significantly increased with dietary arginine levels up to $12.7 \mathrm{~g} / \mathrm{kg}$ diet (Fig. 3; $P<0.05$ ), and there were no differences between $16 \cdot 1$ and $24.5 \mathrm{~g}$ arginine $/ \mathrm{kg}$ diet levels $(P>0.05)$. The levels of 4E-BP mRNA in muscle significantly decreased with dietary arginine levels up to $12 \cdot 7 \mathrm{~g} / \mathrm{kg}$ diet (Fig. 4; $P<0.05$ ); then, the levels remained approximately constant. In the DI, 4E-BP mRNA levels (Fig. 4) were the highest for fish fed with a diet containing $24.5 \mathrm{~g}$ arginine $/ \mathrm{kg}$ diet $(P<0.05)$ and the lowest for fish fed with a diet containing $16 \cdot 1 \mathrm{~g}$ arginine $/ \mathrm{kg}$ diet $(P<0.05)$. The following equations were obtained for 4E-BP mRNA levels in muscle and in DI,

Table 7. Intestine flora of Jian carp (Cyprinus carpio var. Jian) fed diets containing graded levels of dietary arginine

(Mean values with their standard errors for four replicates)

\begin{tabular}{|c|c|c|c|c|c|c|c|c|c|c|c|c|}
\hline \multirow{2}{*}{$\begin{array}{l}\text { Dietary Arg } \\
\text { levels }(\mathrm{g} / \mathrm{kg}) \ldots\end{array}$} & \multicolumn{2}{|c|}{$9 \cdot 8$} & \multicolumn{2}{|c|}{$12 \cdot 7$} & \multicolumn{2}{|c|}{$16 \cdot 1$} & \multicolumn{2}{|c|}{$18 \cdot 5$} & \multicolumn{2}{|c|}{21.9} & \multicolumn{2}{|c|}{24.5} \\
\hline & Mean & SE & Mean & SE & Mean & SE & Mean & SE & Mean & SE & Mean & SE \\
\hline \multicolumn{13}{|c|}{ Intestine flora (log CFU/g intestine content) } \\
\hline Aeromonas hydrophila & $8 \cdot 65^{b}$ & 0.01 & $8 \cdot 40^{\mathrm{a}}$ & 0.05 & $8 \cdot 26^{a}$ & 0.03 & $8 \cdot 29^{a}$ & 0.05 & $8 \cdot 38^{a}$ & 0.02 & $8.56^{\mathrm{b}}$ & $0 \cdot 10$ \\
\hline Escherichia coli & $7 \cdot 96^{d}$ & 0.02 & $7 \cdot 45^{a, b}$ & 0.02 & $7 \cdot 31^{\mathrm{a}}$ & 0.06 & $7 \cdot 41^{\mathrm{a}, \mathrm{b}}$ & 0.07 & $7.55^{\mathrm{b}}$ & 0.03 & $7 \cdot 80^{c}$ & 0.05 \\
\hline Lactobacillus & $5 \cdot 90^{\mathrm{a}}$ & 0.11 & $6 \cdot 48^{\mathrm{b}}$ & 0.01 & $7 \cdot 22^{d}$ & 0.15 & $7 \cdot 14^{d}$ & 0.01 & $7 \cdot 12^{d}$ & 0.05 & $6 \cdot 84^{c}$ & 0.09 \\
\hline
\end{tabular}

$\mathrm{CFU}$, colony-forming units.

a,b,c,d Mean values within a row with unlike superscript letters were significantly different $(P<0.05)$. 


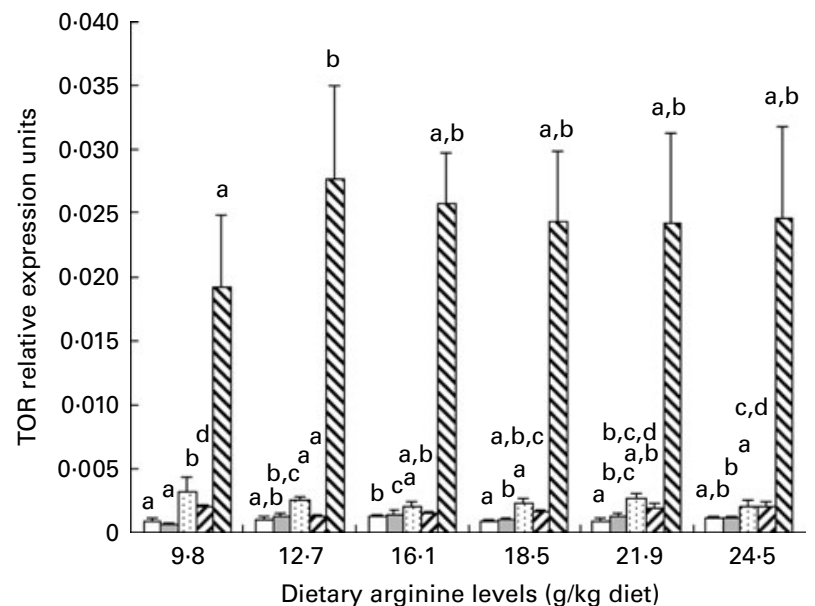

Fig. 2. Relative expression of target of rapamycin (TOR) mRNA in juvenile Jian carp (Cyprinus carpio var. Jian) fed with diets containing graded levels of arginine. Values are means for five fish per treatment, with standard deviations represented by vertical bars $(n 5)$. ${ }^{a, b, c, d}$ Mean values with unlike letters were significantly different $(P<0.05)$. $\square$, Muscle; $\square$, hepatopancreas; $\mathrm{Q}$, proximal intestine; $\mathbb{Z}$, mid intestine; $\mathbb{\mathbb { }}$, distal intestine.

respectively: $Y=0.001-9 \mathrm{E}-05 x+2 \mathrm{E}-06 x^{2}, R^{2} 0.955$, $P<0.05$ and $Y=0.0013-0.0001 x+4 \mathrm{E}-06 x^{2}, R^{2} 0.906$, $P<0 \cdot 05$.

\section{Discussion}

The importance of dietary arginine for normal growth of Jian carp was demonstrated in the present study. SGR increased with higher dietary arginine concentrations up to an optimum level. Similar observations have been reported in Indian major $\operatorname{carp}^{(4,70,71)}$, black sea bream (Sparus macrocephalus) ${ }^{(72)}$, rainbow trout ${ }^{(73)}$ and channel catfish (Ictalurus punctatus) ${ }^{(1)}$. In the present study, FI and FE increased with higher arginine levels up to a level similar to those found in other fish

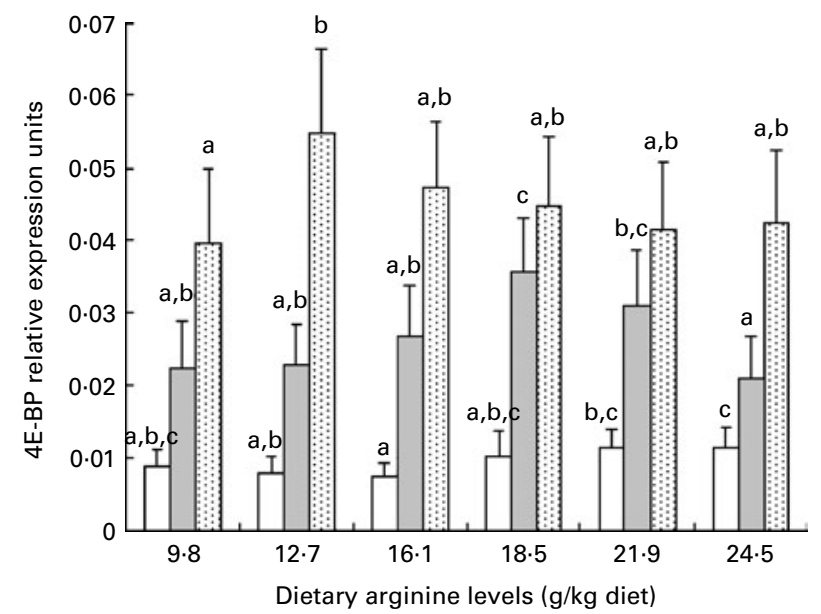

Fig. 3. Relative expression of elF4E-binding protein (4E-BP) mRNA in hepatopancreas, proximal and mid-intestine of juvenile Jian carp (Cyprinus carpio var. Jian) fed with diets containing graded levels of arginine. Values are means for five fish per treatment, with standard deviations represented by vertical bars. ${ }^{\mathrm{a}, \mathrm{b}, \mathrm{c}}$ Mean values with unlike letters were significantly different $(P<0.05)$. $\square$, Hepatopancreas; $\square$, proximal intestine; 8 , mid intestine.

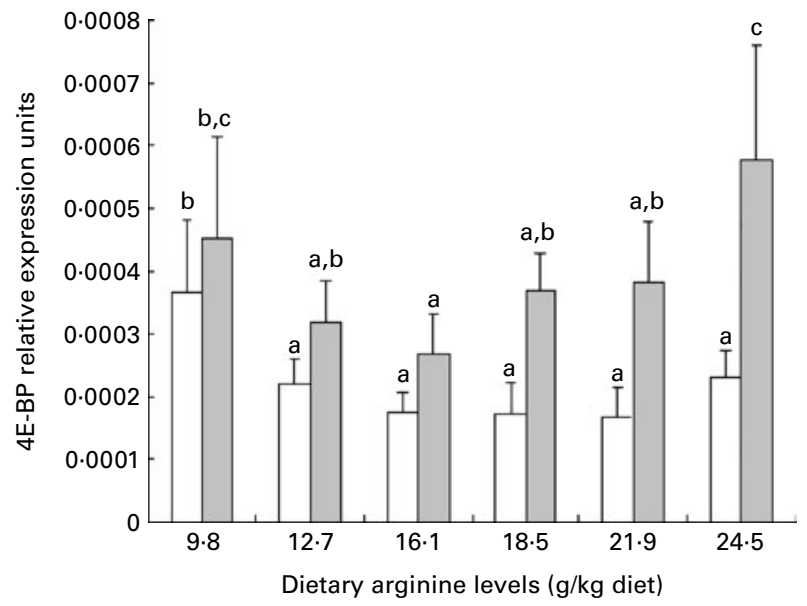

Fig. 4. Relative expression of elF4E-binding protein (4E-BP) mRNA in muscle and distal intestine of juvenile Jian carp (Cyprinus carpio var. Jian) fed with diets containing graded levels of arginine. Values are means for five fish per treatment, with standard deviations represented by vertical bars. ${ }^{\mathrm{a}, \mathrm{b}, \mathrm{c}}$ Mean values with unlike letters were significantly different $(P<0.05)$. $\square$, Muscle; $\square$, distal intestine.

species $^{(4,71)}$. SGR was positively related to FI and FE $(r+0.848, P<0.05 ; r+0.845, P<0 \cdot 05)$. This result indicates that the enhancement of fish growth was partly attributed to the increment in FI and FE. Fish growth mainly involves protein retention in muscle, epithelial and connective tissue ${ }^{(74)}$. A continuous supply of amino acids is required for protein synthesis because proteins are continually used for animal growth and tissue repair ${ }^{(75)}$. In the present study, PRV significantly increased with higher levels of dietary arginine up to an optimum arginine level that supported the highest SGR. Besides protein synthesis, the improvement of fish growth with arginine supplementation might be due to its role as a secretagogue of growth-regulating hormones ${ }^{(76)}$. Fish fed with diets containing arginine above the optimum level did not exhibit additional growth. Similar results have been obtained in a few studies in rainbow trout ${ }^{(77)}$ and Nile tilapia (Oreochromis niloticus) $^{(78)}$, whereas such results were not observed in other species such as carp ${ }^{(79)}$, sea bass ${ }^{(2)}$ and channel catfish ${ }^{(80)}$. The reduction in weight gain with arginine levels above the requirement level might be due to (1) extra energy expenditure for deamination; (2) disturbance of absorption and utilisation of other amino acids; (3) lower palatability of the diet; or (4) toxic effects and stress ${ }^{(81)}$. A reduction of FI was regarded as the primary factor responsible for the depressed growth observed in Atlantic salmon fry ${ }^{(82)}$ and European sea bass ${ }^{(83)}$. The arginine requirement estimated from SGR by using a quadratic regression analysis was $18.0 \mathrm{~g} / \mathrm{kg}$ diet, which corresponded to $55.0 \mathrm{~g} / \mathrm{kg}$ of dietary protein (Fig. 1). This value was higher than that of channel catfish with $33-38 \mathrm{~g} / \mathrm{kg}$ of dietary protein $^{(84)}$ and Japanese flounder (Paralichthys olivaceus) with $41.4 \mathrm{~g} / \mathrm{kg}$ of dietary protein $^{(85)}$ and lower than that of black sea bream with $77 \cdot 4-81 \cdot 3 \mathrm{~g} / \mathrm{kg}$ of dietary protein ${ }^{(72)}$.

Protein deposition was mainly associated with amino acid metabolism in fish ${ }^{(5)}$. Unbalanced dietary amino acid influenced ammonia formation and decreased amino acid 
utilisation and protein retention $^{(86)}$. In the present study, the PAC was lower for fish fed with optimum dietary arginine levels, supporting a higher protein efficiency ratio in this group. Therefore, amino acids were available in an appropriate balance for body protein synthesis with the optimal arginine level. Higher PAC was found in Jian carp fed with a moderate excess of arginine than those fed with the optimal level. Similarly, Tulli et al. ${ }^{(9)}$ observed that there was an increase in plasma ammonia nitrogen concentration in European sea bass fed with plant protein diets under a moderate or large excess of dietary arginine. This higher PAC might be the result of amino acid imbalance and/or catabolism of excessive arginine ${ }^{(77,85)}$. This scenario might explain the poor growth performance in fish fed with diets containing 21.9 and $24.5 \mathrm{~g}$ arginine $/ \mathrm{kg}$ diet. Moreover, Gouillou-Coustans et $a l{ }^{(87)}$ showed that the plasma urea concentration was responsive to arginine intake in turbot (Psetta maxima). Hence, a more extensive study is necessary to investigate the effects of arginine on nitrogen excretion.

Pelletier et $a l .^{(88)}$ found that amino acid metabolism correlated with growth rates in Atlantic cod (Gadus morhua). Moreover, GOT and GPT are considered to be the most important amino acid catabolism enzymes of teleostean fish ${ }^{(6)}$. In the present study, GOT and GPT activities in muscle and hepatopancreas significantly increased with higher dietary arginine concentrations until a certain point; then, the activities decreased with further increases in dietary arginine levels, supporting the PRV results. Similar observations were reported for juvenile Jian carp supplementation with methionine hydroxy analogue in practical diets ${ }^{(10)}$. The present results indicate an efficient use of dietary amino acids for growth when fish are fed with an optimal dietary arginine concentration.

Fish growth is mainly associated with digestive and absorptive ability ${ }^{(11,12)}$. Digestion and absorption of nutrients depend on the activity of digestive enzymes and brush-border membrane enzymes, which are responsible for breaking down and assimilating food ${ }^{(18)}$. Fish exocrine pancreas synthesises and secretes a large number of digestive enzymes into the intestinal lumen, such as trypsin, chymotrypsin, lipase and amylase $^{(19,20)}$. The potential energy of the Na gradient created by the $\mathrm{Na}^{+} / \mathrm{K}^{+}$-ATPase is used by many transport systems to move, for example, phosphate, amino acids or glucose into the cells ${ }^{(89)}$. AKP, an important enzyme in the absorptive process in fish, is considered to be a general marker of nutrient absorption $^{(90)}$, and $\gamma$-GT is involved in peptide transport ${ }^{(91)}$. CK has a key role in the energy metabolism of cells, because it catalyses the transfer of phosphate to creatine in an ATPdependent manner ${ }^{(92)}$. In the present study, trypsin, chymotrypsin and amylase activities in hepatopancreas significantly increased with higher levels of dietary arginine. Similarly, activities of $\mathrm{Na}^{+} / \mathrm{K}^{+}$-ATPase, AKP, $\gamma$-GT and CK in the intestine significantly increased with dietary arginine levels. In addition, SGR was positively related to the activity of these enzymes $\left(r_{\text {trypsin }}+0.895, P<0.05 ; r_{\text {chymotrypsin }}+0.889\right.$, $P<0.05 ; \quad r_{\text {amylase }}+0.854, \quad P<0.05 ; \quad r_{\mathrm{Na}^{+} / \mathrm{K}^{+} \text {-ATPase }}+0.957$, $\left.P<0.01 ; r_{\mathrm{AKP}}+0.921, P<0.01 ; r_{\gamma-\mathrm{GT}}+0.877, P<0.05\right)$. These results demonstrate that the higher growth performance in fish fed with optimal arginine levels was related to a higher activity of enzymes involved in digestion and absorption. Furthermore, studies from our laboratory found that glutamine ${ }^{(33)}$ and lysine ${ }^{(34)}$ improved digestive and absorptive enzyme activities in juvenile Jian carp. To date, information regarding the effect of arginine on the activity of digestion and absorption enzyme is scarce. Evidence from a structural analysis has shown that arginine residues have an important role in digestion and absorption enzymes ${ }^{(28,29,31,32)}$. In addition, arginine metabolites, such as polyamines and $\mathrm{NO}$, might be involved in the beneficial effects on digestive and absorptive enzyme activities. Péres et al. ${ }^{(93)}$ showed that supplementing spermine to microparticulate diets increased pancreatic enzyme activities in sea bass larvae. Fish exocrine pancreas is the main site for digestive enzyme synthesis and secretion $^{(19,20)}$. Studies on mice and pigs indicated that NO has an active role in pancreatic secretion ${ }^{(24,25)}$. Moreover, the enhancement of digestive and absorptive enzyme activities with arginine might be related to the integrity, growth and development of fish digestive organs, which are the foundation of digestion and absorption. Lovett \& Felder ${ }^{(94)}$ reported that the activity of the digestive enzymes was correlated with the growth and development of the hepatopancreas in white shrimp (Penaeus setiferus). In the present study, the hepatopancreas weight and protein content showed a similar trend with the digestive enzyme activities, suggesting a beneficial effect of arginine on hepatopancreas growth and development. The hepatosomatic index of sea bass was increased significantly up to a point and decreased thereafter as dietary arginine levels increased ${ }^{(2)}$. Intestine length, weight and protein content increased with increasing dietary arginine concentrations, suggesting that arginine also stimulated fish intestinal growth and development. Furthermore, folds height was responsive to dietary arginine in the present study, which indicates the improvement of intestinal morphometric integrity. The beneficial effect of arginine on the integrity, growth and development of fish hepatopancreas and intestine might be related to polyamines. Polyamines (putrescine, spermidine and spermine), important products of arginine degradation in cells, are essential for cell proliferation and differentiation ${ }^{(95)}$. Like other intestinal mucosal cells $^{(96)}$, fish brush-border membrane might depend on polyamines for proliferation and differentiation. However, more studies are required to elucidate a more detailed mode in which arginine mediates the digestive and absorptive ability in fish.

Intestinal microbiota has an important role in fish health status $^{(36)}$, and alterations in microbial balance might result in detrimental effects to hosts ${ }^{(37)}$. In the present study, Aeromonas and E. coli gradually decreased with dietary arginine levels, whereas Lactobacillus gradually increased. Although limited information is available regarding the effects of arginine on fish intestinal microbial populations, similar observations were reported in juvenile Jian carp supplemented with methionine ${ }^{(35)}$. The underlying mechanism needs to be further investigated.

In the present study, the hepatopancreas and intestine protein content increased with increasing dietary arginine, 
suggesting the improvement of protein synthesis. Translation initiation, the limiting step in protein synthesis, is regulated by the TOR signalling pathway ${ }^{(41)}$. A study from our laboratory indicated that TOR was involved in the regulation of fish IEC protein synthesis with Gln supplementation (J Jiang and XQ Zhou, unpublished results). Fish growth consists primarily of an increase in body muscle mass by protein synthesis and accretion ${ }^{(97)}$. Seiliez et al. ${ }^{(42)}$ showed that re-feeding induces the activation of the TOR pathway in rainbow trout muscle by enhancing the phosphorylation of TOR and 4E$\mathrm{BP} 1$. In liver, a protein anabolic response was accompanied by increased phosphorylation of 4E-BP1 in human and rats after a protein meal ${ }^{(98-100)}$ and elevated phosphorylation of TOR in rainbow trout ${ }^{(43)}$. Moreover, arginine regulated $4 \mathrm{E}-$ BP1 phosphorylation through the mTOR signalling pathway in IEC6 and in IEC18 rat intestinal epithelial ${ }^{(15)}$ and intestinal porcine epithelial cell $-1^{(16)}$. These studies indicate a stimulation of an amino acid-sensitive target of a rapamycin signalling pathway involved in regulating protein accretion in mammals and fish. To our knowledge, the present study is the first to determine the effect of dietary arginine on the mRNA expression of major kinases involved in the TOR pathway in a fish species. Extending these observations, we reported here that patterns of difference in mRNA levels of $4 \mathrm{E}-\mathrm{BP}$, the inhibitor of translation, were properly opposite to TOR mRNA levels in the hepatopancreas, muscle and intestine, suggesting that arginine might decrease the inhibition of translation and increase TOR activity, thus improving the synthesis of proteins. These results suggest that arginine might improve protein synthesis in fish through the TOR pathway. These novel findings might explain our observation that arginine enhanced fish protein retention, intestinal enzyme activities and hepatopancreatic and intestinal growth. It is worth noting, however, that patterns of difference in TOR and 4E-BP mRNA levels in the PI and MI were opposite to that in hepatopancreas, muscle and DI. Understanding the underlying mechanisms require further studies.

Therefore, we conclude that arginine could improve fish growth and intestinal enzyme activities and maintain an intestinal microbial balance by promoting the growth of health-promoting bacteria and decreasing the growth of harmful bacteria in juvenile Jian carp. The arginine requirement of Jian carp was estimated by using a quadratic regression analysis of SGR data to dietary arginine levels reported to be at $18.0 \mathrm{~g} / \mathrm{kg}$ diet, corresponding to $55.0 \mathrm{~g} / \mathrm{kg}$ dietary protein for the maximum growth of this fish. Finally, TOR and $4 \mathrm{E}-\mathrm{BP}$ mRNA levels in different tissues might explain the arginineenhanced fish growth and digestive and absorptive ability.

\section{Acknowledgements}

The present study was supported by the National Department Public Benefit Research Foundation (Agriculture) of China (201003020), the Program for New Century Excellent Talents in University (NCET-08-0905) and the Key Project of Chinese Ministry of Education (208120). G. C. was responsible for the feeding trial, statistical analysis and preparing the manuscript. L. F. prepared the manuscript and proofread the manuscript. Y. L. prepared the manuscript and edited the manuscript. We thank J. J., K. H. and Wu Pei for their technical assistance for the real time-quantitative PCR analysis. W. J. prepared the manuscript and created the tables. S. L. researched the references and created the figures. X. Z. provided valuable advice on the study design and discussion. The authors declare no conflicts of interest.

\section{References}

1. Wilson RP (2002) Amino acids and proteins. In Fish Nutrition, 3rd ed., pp. 143-181 [JE Halver and RW Hardy, editors]. London: Academic Press.

2. Tibaldi E, Tulli F \& Lanari D (1994) Arginine requirement and effect of different dietary arginine and lysine levels for fingerling sea bass (Dicentrarchus labrax). Aquaculture 127, 207-218

3. Luzzana U, Hardy RW \& Halver JE (1998) Dietary arginine requirement of fingerling coho salmon (Oncorbynchus kisutch). Aquaculture 163, 137-150.

4. Ahmed I \& Khan MA (2004) Dietary arginine requirement of fingerling Indian major carp, Cirrbinus mrigala (Hamilton). Aquacult Nutr 10, 217-225.

5. Sveier H, Raae AJ \& Lied E (2000) Growth and protein turnover in Atlantic salmon (Salmo salar L.); the effect of dietary protein level and protein particle size. Aquaculture 185, $101-120$

6. Cowey CB \& Walton MJ (1989) Intermediary metabolism. In Fish Nutrition, 2nd ed., pp. 259-329 [JE Halver, editor]. San Diego, CA: Academic Press.

7. Vijayan MM, Mommsen TP, Giemet HC, et al. (1996) Metabolic effects of cortisol treatment in a marine teleost, the sea raven. J Exp Biol 199, 1509-1514.

8. Lim CB, Chew SF, Anderson PM, et al. (2001) Reduction in the rates of protein and amino acid catabolism to slow down the accumulation of endogenous ammonia: a strategy potentially adopted by mudskippers (Periophthalmodon schlosseri and Boleophthalmus boddaerti) during aerial exposure in constant darkness. J Exp Biol 204, 1605-1614.

9. Tulli F, Vachot C, Tibaldi E, et al. (2007) Contribution of dietary arginine to nitrogen utilisation and excretion in juvenile sea bass (Dicentrarchus labrax) fed diets differing in protein source. Comp Biochem Physiol A Mol Integr Physiol 147, 179-188.

10. Xiao WW, Feng L, Liu Y, et al. (2011) Effects of dietary methionine hydroxy analogue supplement on growth, protein deposition and intestinal enzymes activities of juvenile Jian carp (Cyprinus carpio var. Jian). Aquacult Nutr 17, 408-417.

11. Harpaz S \& Uni Z (1999) Activity of intestinal mucosal brush border membrane enzymes in relation to the feeding habits of three aquaculture fish species. Comp Biochem Physiol A Mol Integr Physiol 124, 155-160.

12. Mitra G, Mukhopadhyay PK \& Ayyappan S (2008) Modulation of digestive enzyme activities during ontogeny of Labeo rohita larvae fed ascorbic acid enriched zooplankton. Comp Biochem Physiol A Mol Integr Physiol 149, 341-350.

13. Pedersen HE \& Sissons JW (1984) Effect of antigenic soyabean protein on the physiology and morphology of the gut in the preruminant calf. Can J Anim Sci 64, 183-184.

14. Jaworek J, Jachimczak B, Tomaszewska R, et al. (2000) Protective action of lipopolysaccharidesin rat caeruleininduced pancreatitis: role of nitric oxide. Digestion $\mathbf{6 2}$, $1-13$. 
15. Ban H, Shigemitsu K, Yamatsuji T, et al. (2004) Arginine and leucine regulate p70 S6 kinase and 4E-BP1 in intestinal epithelial cells. Int J Mol Med 13, 537-543.

16. Tan B, Yin YL, Kong XF, et al. (2010) L-Arginine stimulates proliferation and prevents endotoxin-induced death of intestinal cells. Amino Acids 38, 1227-1235.

17. Gurbuz AT, Kunzelman J \& Ratzer EE (1998) Supplemental dietary arginine accelerates intestinal mucosal regeneration and enhances bacterial clearance following radiation enteritis in rats. J Surg Res 74, 149-154.

18. Klein S, Cohn SM \& Alpers DH (2006) Alimentary tract in nutrition. In Modern Nutrition in Health and Disease, 10th ed., pp. 1115-1142 [ME Shils, JA Olson, M Shike and AC Ross, editors]. Baltimore: Lippincott Williams and Wilkins.

19. Zambonino Infante JL \& Cahu CL (2001) Ontogeny of the gastrointestinal tract of marine fish larvae. Comp Biochem Physiol C Toxicol Pharmacol 130, 477-487.

20. Gilloteaux J, Kashouty R \& Yono N (2008) The perinuclear space of pancreatic acinar cells and the synthetic pathway of zymogen in Scorpaena scrofa L.: ultrastructural aspects. Tissue Cell 40, 7-20.

21. Villanueva J, Vanacore R, Goicoechea O, et al. (1997) Intestinal alkaline phosphatase of the fish Cyprinus carpio: regional distribution and membrane association. J Exp Zool 279, 347-355.

22. Vasilijević A, Buzadžić B, Korać A, et al. (2007) Beneficial effects of L-arginine-nitric oxide-producing pathway in rats treated with alloxan. J Physiol 584, 921-933.

23. Ivarsson R, Quintens R, Dejonghe S, et al. (2005) Redox control of exocytosis: regulatory role of NADPH, thioredoxin, and glutaredoxin. Diabetes 54, 2132-2142.

24. DiMagno MJ, Hao Y, Tsunoda Y, et al. (2004) Secretagoguestimulated pancreatic secretion is differentially regulated by constitutive nitric oxide synthase isoforms in mice. Am J Physiol Gastrointest Liver Physiol 286, G428-G436.

25. Holst JJ, Rasmussen TN \& Schmidt P (1994) Role of nitric oxide in neurally induced pancreatic exocrine secretion in pigs. Am J Physiol Gastrointest Liver Physiol 266, G206-G213.

26. Cohen T, Gertler A \& Birk Y (1981) Pancreatic proteolytic enzymes from carp (Cyprinus carpio) - I purification and physical properties of trypsin, chymotrypsin, elastase and carboxypeptidase B. Comp Biochem Physiol B Biochem Mol Biol 69, 639-646.

27. Frøystad MK, Lilleeng E, Sundby A, et al. (2006) Cloning and characterization of alpha-amylase from Atlantic salmon (Salmo salar L.). Comp Biochem Physiol A Mol Integr Physiol 145, 479-492.

28. Sun HW, Hui CF \& Wu JL (1998) Cloning, characterization, and expression in Escherichia coli of three creatine kinase muscle isoenzyme cDNAs from carp (Cyprinus carpio) striated muscle. J Bio Chem 273, 33774-33780.

29. Chen XW \& Shi ZY (2007) cDNA sequence analysis and tertiary structure prediction of alkaline phosphatase from Paralichthys olivaceus. Chin J Biochem Mol Biol 23, 442-449.

30. De Pont J, Schoot BM, Van Prooijen-van Eeden A, et al. (1977) An essential arginine residue in the ATP-binding centre of $\left(\mathrm{Na}^{+}+\mathrm{K}^{+}\right)$-ATPase. Biochim Biophys Acta $\mathbf{4 8 2}$, 213-227.

31. Jacobsen MD, Pedersen PA \& Jorgensen PL (2002) Importance of Na,K-ATPase residue $\alpha 1-\mathrm{Arg}^{544}$ in the segment $\mathrm{Arg}^{544}-\mathrm{Asp}^{567}$ for high-affinity binding of ATP, ADP, or MgATP. Biochemistry 41, 1451-1456.
32. Stole E \& Meister A (1991) Interaction of $\boldsymbol{\gamma}$-glutamyl transpeptidase with glutathione involves specific arginine and lysine residues of the heavy subunit. J Biol Chem 266, $17850-17857$.

33. Lin Y \& Zhou XQ (2006) Dietary glutamine supplementation improves structure and function of intestine of juvenile Jian carp (Cyprinus carpio var. Jian). Aquaculture 256, 389-394.

34. Zhou XQ, Zhao CR \& Lin Y (2007) Compare the effect of diet supplementation with uncoated or coated lysine on juvenile Jian Carp (Cyprinus carpio var. Jian). Aquacult Nutr 13, 457-461.

35. Tang L, Wang GX, Jiang J, et al. (2009) Effect of methionine on intestinal enzymes activities, microflora and humoral immune of juvenile Jian carp (Cyprinus carpio var. Jian). Aquacult Nutr 15, 477-483.

36. Nayak SK (2010) Role of gastrointestinal microbiota in fish. Aquac Res 41, 1553-1573.

37. Trust TJ (1975) Faculative anaerobic bacteria in the digestive tract of chum salmon (Oncorbynchus keta) maintained in fresh water under defined culture conditions. Appl Environ Microbiol 29, 663-668.

38. Liu Y, Feng L, Jiang J, et al. (2009) Effects of dietary protein levels on the growth performance, digestive capacity and amino acid metabolism of juvenile Jian carp (Cyprinus carpio var. Jian). Aquac Res 40, 1073-1082.

39. Chamorro S, de Blas C, Grant G, et al. (2010) Effect of dietary supplementation with glutamine and a combination of glutamine-arginine on intestinal health in twenty-five-dayold weaned rabbits. J Anim Sci 88, 170-180.

40. Anthony TG, Reiter AK, Anthony JC, et al. (2001) Deficiency of dietary EAA preferentially inhibits mRNA translation of ribosomal proteins in liver of meal-fed rats. Am J Physiol Endocrinol Metab 281, E430-E439.

41. Holz MK, Ballif BA, Gygi SP, et al. (2005) mTOR and S6K1 mediate assembly of the translation preinitiation complex through dynamic protein interchange and ordered phosphorylation events. Cell 123, 569-580.

42. Seiliez I, Gabillard JC, Skiba-Cassy S, et al. (2008) An in vivo and in vitro assessment of TOR signaling cascade in rainbow trout (Oncorbynchus mykiss). Am J Physiol Regul Integr Comp Physiol 295, R329-R335.

43. Skiba-Cassy S, Lansard M, Panserat S, et al. (2009) Rainbow trout genetically selected for greater muscle fat content display increased activation of liver TOR signaling and lipogenic gene expression. Am J Physiol Regul Integr Comp Physiol 297, R1421-R1429.

44. Sun XY, Zhang JS, Shi YH, et al. (1995) Studies on the genetic characteristic of Jian carp (Cyprinus carpio var. Jian) in China. Aquaculture 137, 276-277.

45. Dong ZJ \& Yuan XH (2002) The utilizations of heterosis in common carp in China. Aquac Asia 12, 14-15.

46. Cheng HL, Sun SP, Peng YX, et al. (2009) cDNA sequence and tissues expression analysis of lipoprotein lipase from common carp (Cyprinus carpio var. Jian). Mol Biol Rep 37, 2665-2673.

47. Tan LN, Feng L, Liu Y, et al. (2011) Growth, body composition and intestinal enzyme activities of juvenile Jian carp (Cyprinus carpio var. Jian) fed graded levels of dietary zinc. Aquacult Nutr 17, 338-345.

48. Ling J, Feng L, Liu Y, et al. (2010) Effect of dietary iron levels on growth, body composition and intestinal enzyme activities of juvenile Jian carp (Cyprinus carpio var. Jian). Aquacult Nutr 16, 616-624. 
49. He W, Zhou XQ, Feng L, et al. (2009) Dietary pyridoxine requirement of juvenile Jian carp (Cyprinus carpio var. Jian). Aquacult Nutr 15, 402-408.

50. Wen ZP, Zhou XQ, Feng L, et al. (2009) Effect of dietary pantothenic acid supplement on growth, body composition and intestinal enzyme activities of juvenile Jian carp (Cyprinus carpio var. Jian). Aquacult Nutr 15, 470-476.

51. Jiang WD, Feng L, Liu Y, et al. (2009) Growth, digestive capacity and intestinal microflora of juvenile Jian carp (Cyprinus carpio var. Jian) fed graded levels of dietary inositol. Aquac Res 40, 955-962.

52. Li W, Zhou XQ, Feng L, et al. (2010) Effect of dietary riboflavin on growth, feed utilization, body composition and intestinal enzyme activities of juvenile Jian carp (Cyprinus carpio var. Jian). Aquacult Nutr 16, 137-143.

53. Huang HH, Feng L, Liu Y, et al. (2011) Effects of dietary thiamin supplement on growth, body composition and intestinal enzyme activities of juvenile Jian carp (Cyprinus carpio var. Jian). Aquacult Nutr 17, e223-e240.

54. National Research Council (NRC) (1993) Nutrient Requirements of Domestic Animals. In Nutrient Requirements of Fish. Washington, DC: National Academy Press.

55. Bohne VJB, Lundebye AK \& Hamre K (2008) Accumulation and depuration of the synthetic antioxidant ethoxyquin in the muscle of Atlantic salmon (Salmo salar L.). Food Chem Toxicol 46, 1834-1843.

56. Wu G, Davis PK, Flynn NE, et al. (1997) Endogenous synthesis of arginine plays an important role in maintaining arginine homeostasis in postweaning growing pigs. $J$ Nutr 127, 2342-2349.

57. Jiang WD, Feng L, Liu Y, et al. (2010) Lipid peroxidation, protein oxidant and antioxidant status of muscle, intestine and hepatopancreas for juvenile Jian carp (Cyprinus carpio var. Jian) fed graded levels of myo-inositol. Food Chem 120, 692-697.

58. Berdikova Bohne VJ, Hamre K \& Arukwe A (2007) Hepatic metabolism, phase I and II biotransformation enzymes in Atlantic salmon (Salmo salar, L.) during a 12 week feeding period with graded levels of the synthetic antioxidant, ethoxyquin. Food Chem Toxicol 45, 733-746.

59. Association of Official Analytical Chemists (1998) Official Methods of Analysis, 16th ed. Washington, DC: Association of Official Analytical Chemists.

60. Bergmeyer HU \& Bernt E (1974) Glutamate-oxaloacetate transaminase. In Methods of Enzymatic Analysis, 2nd ed., pp. 727-733 [HU Bergmeyer, editor]. New York, NY: Academic Press.

61. Bergmeyer HU \& Bernt E (1974) Glutamate-pyruvate transaminase. In Methods of Enzymatic Analysis, 2nd ed., pp. 752-758 [HU Bergmeyer, editor]. New York, NY: Academic Press.

62. Tantikitti C \& Chimsung N (2001) Dietary lysine requirement of freshwater catfish (Mystus nemurus Cuv. \& Val.). Aquac Res 32, 135-141.

63. Hummel BCW (1959) A modified spectrophotometric determination of chymotrypsin, trypsin, and thrombin. Can J Physiol Pharm 37, 1393-1399.

64. Furné M, Hidalgo MC, Lo'pez A, et al. (2005) Digestive enzyme activities in Adriatic sturgeon Acipenser naccarii and rainbow trout Oncorbynchus mykiss. A comparative study. Aquaculture 250, 391-398.

65. Bessey OA, Lowry OH \& Brock MJ (1946) A method for the rapid determination of alkaline phosphatase with five cubic millimeters of serum. J Biol Chem 164, 321-329.
66. McCormick SD (1993) Methods for Nonlethal Gill Biopsy and measurement of $\mathrm{Na}^{+}, \mathrm{K}^{+}$-ATPase activity. Can J Fish Aquat Sci 50, 656-658.

67. Bauermeister A, Lewendon A, Ramage PIN, et al. (1983) Distribution and some properties of the glutathione S-transferase and $\gamma$-glutamyl transpeptidase activities of rainbow trout. Comp Biochem Physiol C Toxicol Pharmacol 74, 89-93.

68. Tanzer ML \& Gilvarg C (1959) Creatine and creatine kinase measurement. J Biol Chem 234, 3201-3204.

69. Refstie S, Landsverk T, Bakke-McKellep AM, et al. (2006) Digestive capacity, intestinal morphology, and microflora of 1-year and 2-year old Atlantic cod (Gadus morhua) fed standard or bioprocessed soybean meal. Aquaculture 261, 269-284.

70. Murthy HS \& Varghese TJ (1995) Arginine and histidine requirement of the Indian major carp. Labeo rohita. Aquacult Nutr 1, 235-239.

71. Abidi SF \& Khan MA (2009) Dietary arginine requirement of fingerling Indian major carp, Labeo rohita (Hamilton) based on growth, nutrient retention efficiencies, RNA/DNA ratio and body composition. J Appl Ichthyol 25, 707-714.

72. Zhou F, Xiong W, Xiao JX, et al. (2010) Optimum arginine requirement of juvenile black sea bream, Sparus macrocephalus. Aquac Res 41, e418-e430.

73. Walton MJ, Cowey CB, Coloso RM, et al. (1986) Dietary requirements of rainbow trout for tryptophan, lysine and arginine determined by growth and biochemical measurements. Fish Physiol Biochem 2, 161-169.

74. De Silva SS \& Anderson TA (1995) Fish Nutrition in Aquaculture. London: Chapman \& Hall.

75. Shiau SY (1998) Nutrient requirements of penaeid shrimps. Aquaculture 164, 77-93.

76. Mommsen TP (2001) Paradigms of growth in fish. Comp Biochem Physiol B Biochem Mol Biol 129, 207-219.

77. Fournier V, Gouillou-Coustans MF, Metailler R, et al. (2003) Excess dietary arginine affects urea excretion but does not improve N utilisation in rainbow trout Oncorbynchus mykiss and turbot Psetta maxima. Aquaculture 217, 559-576.

78. Santiago CB \& Lovell RT (1988) Amino acid requirements for growth of Nile tilapia. J Nutr 118, 1540-1546.

79. Nose T. (1979) Summary report on the requirements of essential amino acids for carp. In Finfish Nutrition and Fish Feed Technology, pp. 145-156 [JE Halver and K Tiews, editors]. Berlin: Heenemann.

80. Robinson EH, Wilson RP \& Poe WE (1981) Arginine requirement and apparent absence of a lysine-arginine antagonist in fingerling channel catfish. $J$ Nutr 111, 46-52.

81. Walton MJ. (1985) Aspects of amino acid metabolism in teleost fish. In Nutrition and Feeding in Fish, 1st ed., pp. 47-67 [CB Cowey, A M Mackie and JG Bell, editors]. London: Academic Press.

82. Xavier R, Wauters JB, Bodin N, et al. (2006) Maintenance threonine requirement and efficiency of its use for accretion of whole-body threonine and protein in Atlantic salmon (Salmo salar L.) fry. BrJ Nutr 95, 234-245.

83. Tulli F, Messina M, Calligaris M, et al. (2010) Response of European sea bass (Dicentrarchus labrax) to graded levels of methionine (total sulfur amino acids) in soya protein-based semi-purified diets. Br J Nutr 104, 664-673.

84. Buentello JA \& Gatlin DM III (2000) The dietary arginine requirement of channel catfish (Ictalurus punctatus) is influenced by endogenous synthesis of arginine from glutamic acid. Aquaculture 188, 311-321. 
85. Alam MS, Teshima S, Koshio S, et al. (2002) Arginine requirement of juvenile Japanese flounder Paralichthys olivaceus estimated by growth and biochemical parameters. Aquac Res 205, 127-140.

86. Dabrowski K \& Guderley H (2002) Intermediary metabolism. In Fish Nutrition, 3rd ed., pp. 333-358 [JE Halver and RW Hardy, editors]. London: Academic Press.

87. Gouillou-Coustans MF, Fournier V, Metailler R, et al. (2002) Dietary arginine degradation is a major pathway in ureagenesis in turbot (Psetta Maxima). Comp Biochem Physiol A Mol Integr Physiol 132, 305-319.

88. Pelletier D, Dutil JD, Blier P, et al. (1994) Relation between growth rate and metabolic organization of white muscle, liver and digestive tract in cod, Gadus morbua. Comp Biochem Physiol B Biochem Mol Biol 164, 179-190.

89. Geering K (1990) Subunit assembly and functional maturation of Na,K-ATPase. J Membrane Biol 115, 109-121.

90. Suzer C, Aktülün S, Coban D, et al. (2007) Digestive enzyme activities in larvae of sharpsnout seabream (Diplodus puntazzo). Comp Biochem Physiol A Mol Integr Physiol 148, 470-477.

91. Griffith OW \& Meister A (1980) Excretion of cysteine and gamma-glutamylcysteine moieties in human and experimental animal gamma-glutamyl transpeptidase deficiency. Proc Natl Acad Sci U S A 77, 3384-3387.

92. Decking UKM, Alves C, Wallimann T, et al. (2001) Functional aspects of creatine kinase isoenzymes in endothelial cells. Am J Physiol Cell Physiol 281, C320-C328.
93. Péres A, Cahu CL \& Zambonino-Infante JL (1997) Dietary spermine supplementation induces intestinal maturation in sea bass (Dicentrarchus labrax) larvae. Fish Physiol Biochem 16, 479-485.

94. Lovett DL \& Felder DL (1990) Ontogenetic change in digestive enzyme activity of larval and postlarval white shrimp Penaeus setiferus (Crustacea Decapoda, Penaeidae). Biol Bull 178, 144-159.

95. Li P, Mai KS, Trushenski J, et al. (2009) New developments in fish amino acid nutrition: towards functional and environmentally oriented aquafeeds. Amino Acids 37, 43-53.

96. Wang WW, Qiao SY \& Li DF (2009) Amino acids and gut function. Amino Acids 37, 105-110.

97. Rønnestad I, Thorsen A \& Finn RN (1999) Fish larval nutrition: a review of recent advances in roles of amino acids. Aquaculture 177, 201-216.

98. Shah OJ, Anthony JC, Kimball SR, et al. (2000) 4E-BP1 and S6K1: translational integration sites for nutritional and hormonal information in muscle. Am J Physiol Endocrinol Metab 279, E715-E729.

99. Long W, Saffer L, Wei L, et al. (2000) Amino acids regulate skeletal muscle PHAS-I and p70 S6-kinase phosphorylation independently of insulin. Am J Physiol Endocrinol Metab 279, E301-E306.

100. Balage M, Sinaud S, Prod'homme M, et al. (2001) Amino acids and insulin are both required to regulate assembly of the eIF4E eIF4G complex in rat skeletal muscle. $A m J$ Physiol Endocrinol Metab 281, E565-E574. 